\title{
Geochemistry and hydrology of perched groundwater springs: assessing elevated uranium concentrations at Pigeon Spring relative to nearby Pigeon Mine, Arizona (USA)
}

\author{
Kimberly R. Beisner ${ }^{1}$ • Nicholas V. Paretti ${ }^{1}$ - Fred D. Tillman ${ }^{1}$ • David L. Naftz ${ }^{2}$. \\ Donald J. Bills ${ }^{3} \cdot$ Katie Walton-Day ${ }^{4}$. Tanya J. Gallegos ${ }^{5}$
}

Received: 10 June 2016 / Accepted: 31 October 2016 / Published online: 23 November 2016

(C) The Author(s) 2016. This article is published with open access at Springerlink.com

\begin{abstract}
The processes that affect water chemistry as the water flows from recharge areas through breccia-pipe uranium deposits in the Grand Canyon region of the southwestern United States are not well understood. Pigeon Spring had elevated uranium in $1982(44 \mu \mathrm{g} / \mathrm{L})$, compared to other perched springs $(2.7-18 \mu \mathrm{g} / \mathrm{L})$, prior to mining operations at the nearby Pigeon Mine. Perched groundwater springs in an area around the Pigeon Mine were sampled between 2009 and 2015 and compared with material from the Pigeon Mine to better understand the geochemistry and hydrology of the area. Two general groups of perched groundwater springs were identified from this study; one group is characterized by calcium sulfate type water, low uranium activity ratio ${ }^{234} \mathrm{U} /{ }^{238} \mathrm{U}$ (UAR) values, and a mixture of water with some component of modern water, and the other group by calcium-magnesium sulfate type water, higher UAR values, and radiocarbon ages indicating recharge on the order of several thousand years ago. Multivariate statistical principal components analysis of Pigeon Mine and spring samples indicate $\mathrm{Cu}, \mathrm{Pb}, \mathrm{As}, \mathrm{Mn}$,
\end{abstract}

Electronic supplementary material The online version of this article (doi:10.1007/s10040-016-1494-8) contains supplementary material, which is available to authorized users.

Kimberly R. Beisner

kbeisner@usgs.gov

1 US Geological Survey, 520 N. Park Ave., Tucson, AZ 85719, USA

2 US Geological Survey, 3162 Bozeman, Helena, MT 59601, USA

3 US Geological Survey, 2255 North Gemini Drive, Flagstaff, AZ 86001, USA

4 US Geological Survey, W 6th Ave and Kipling St, Lakewood, CO 80225, USA

5 US Geological Survey, 12201 Sunrise Valley Drive, Reston, VA 20192, USA and $\mathrm{Cd}$ concentrations distinguished mining-related leachates from perched groundwater springs. The groundwater potentiometric surface indicates that perched groundwater at Pigeon Mine would likely flow toward the northwest away from Pigeon Spring. The geochemical analysis of the water, sediment and rock samples collected from the Snake Gulch area indicate that the elevated uranium at Pigeon Spring is likely related to a natural source of uranium upgradient from the spring and not likely related to the Pigeon Mine.

Keywords Mining $\cdot$ Hydrochemistry $\cdot$ USA $\cdot$ Groundwater age $\cdot$ Radioactive isotopes

\section{Introduction}

Changes in chemistry that occur as water flows from source areas through breccia-pipe uranium deposits in the Grand Canyon region (USA) are not well understood. Snake Gulch and Jumpup Canyon are tributaries to Kanab Creek located about $30 \mathrm{~km}$ north of Grand Canyon National Park (GRCA) where Kanab Creek ultimately flows into the Colorado River. Snake Gulch and Jumpup Canyon were chosen for a focused geochemical study because there is a reclaimed breccia pipe uranium mine (Pigeon Mine), collapse features and unmined breccia pipes, and several perched groundwater springs in the drainages.

GRCA in Arizona is a United Nations World Heritage Site (UNESCO 2016) and an international tourist destination. The Grand Canyon Region is a home or sacred place of origin to many Native Americans and its cultural significance goes back thousands of years. The Colorado River, which runs through Grand Canyon, is a primary source of drinking and irrigation water for millions of people in the USA and Mexico. The Grand Canyon region is also believed to host some of the 
highest grade uranium ore in the United States (Alpine and Brown 2010). In 1956, high-grade uranium ore was discovered in the Orphan Lode copper mine, just $3.2 \mathrm{~km}$ west of Grand Canyon Village on the South Rim of Grand Canyon National Park, and thus began the era of uranium exploration and mining in the area (Alpine and Brown 2010). Uranium exploration and mining activity roughly tracked the price of uranium over time, with increased price and activity beginning in the late 1970s and declining price and activity in the early 1990s. A brief uranium price spike in 2007 prompted renewed interest in deposits in the area, and by 2009 over 10,000 mining claims had been located in the Grand Canyon region (US Department of the Interior 2012). In 2012, then US Secretary of the Interior Ken Salazar signed a Record of Decision (ROD) to withdraw over 1 million acres in three segregation areas (north, east and south) of federal land in the Grand Canyon region from new uranium mining activities for the next 20 years, subject to valid existing rights (Fig. 1; US Department of the Interior 2012). A key factor in the decision for the withdrawal was the limited amount of scientific data and resulting uncertainty on potential impacts of uranium mining activities on cultural, biological, and water resources in the area.

Since 2012, the US Geological Survey (USGS) has planned and conducted scientific investigations to address the uncertainties of potential uranium-mining impacts noted in the ROD. Investigations related to regional water resources include gaining a better understanding of the direction and rate of groundwater flow in the area, and understanding what constitutes "background" or naturally occurring concentrations of uranium and associated trace elements in groundwater. There are limited groundwater data available from the Grand Canyon area, owing to the remoteness of the area and depth to the regional groundwater system (over $1,000 \mathrm{~m}$ in some areas). Water-quality data collected from springs are the primary source of information for the Grand Canyon region groundwater studies. The USGS has analyzed samples from 36 springs in the North Rim area of the Grand Canyon (USGS 2015) and the highest dissolved uranium concentration at any of the North Rim sites is from Pigeon Spring (Fig. 2). Pigeon Spring is located just over $1.6 \mathrm{~km}$ from the former Pigeon Mine uranium mine, making understanding the water chemistry at the spring, and the potential hydrologic connection between the mine and the spring, very important. If there is evidence of a connection between the mine and the spring, then the water chemistry at the spring is indicative of what could be expected in groundwater that has been impacted by mining. Alternatively, if there is no evidence of a connection between the two, then the water chemistry at the spring, including the relatively elevated uranium concentrations, must

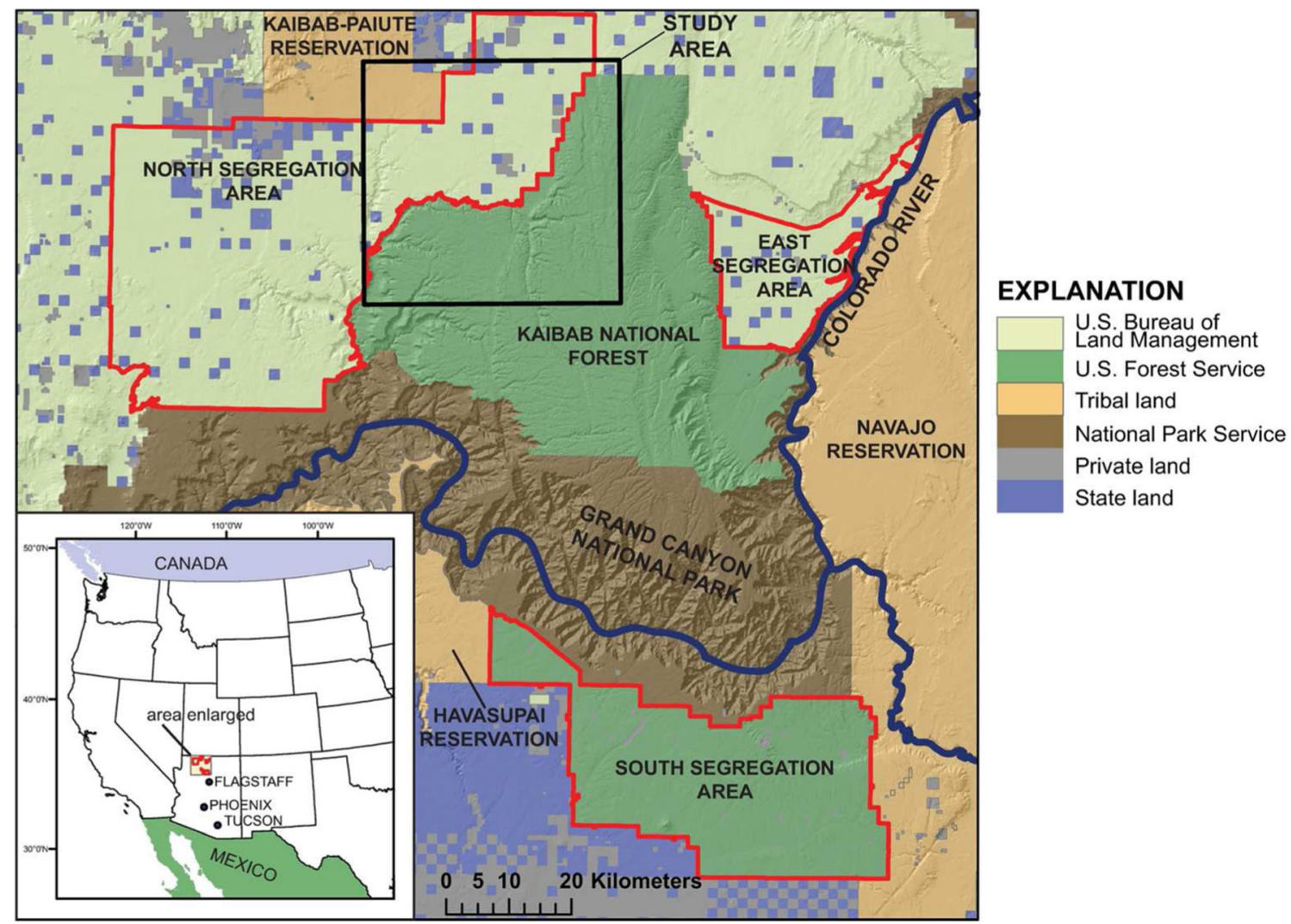

Fig. 1 Regional area map showing study area in Arizona, with detail of land ownership and uranium mining segregation areas withdrawn from new uranium mining activities for 20 years by the 2012 record of decision (US Department of Interior 2012) 


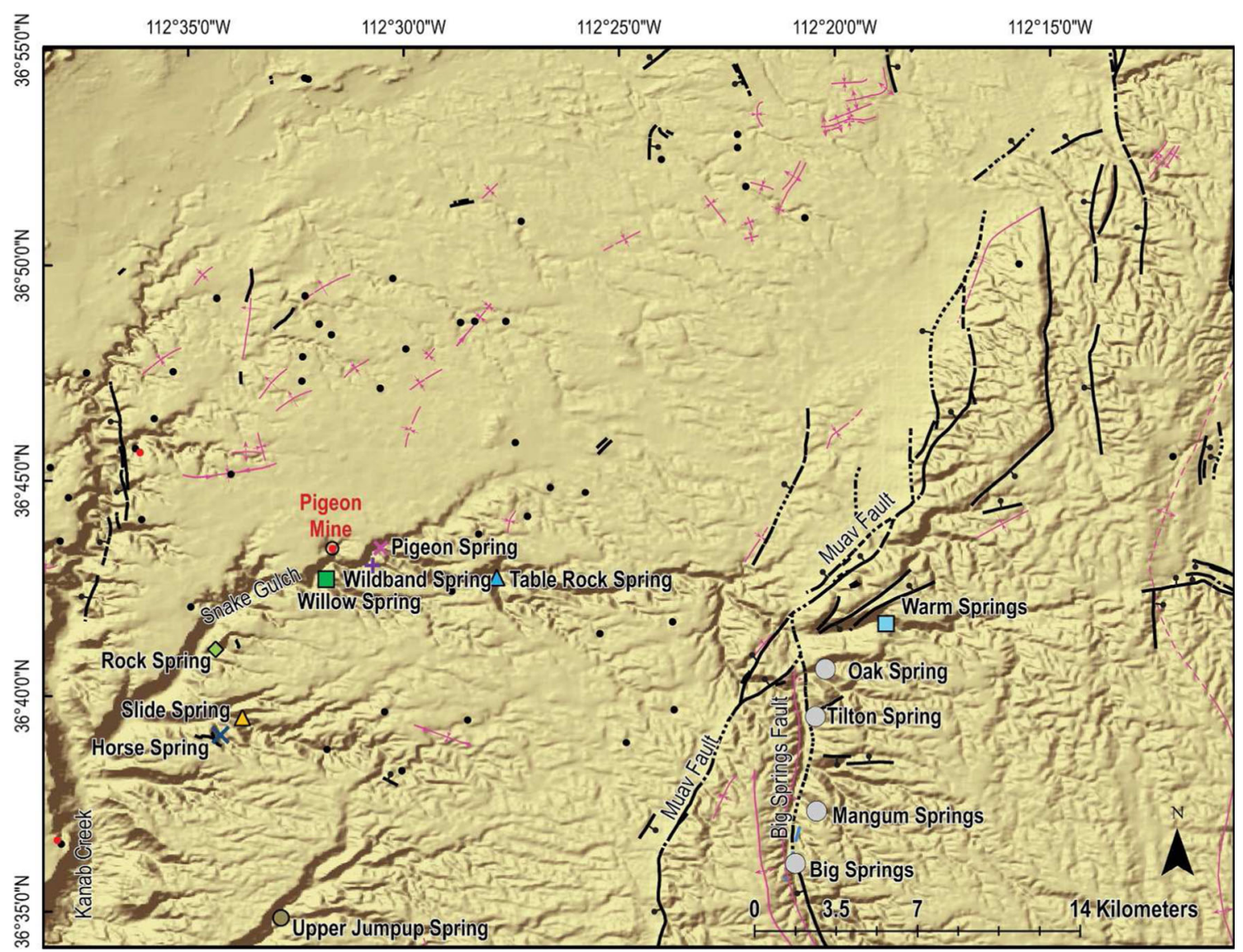

Fig. 2 Study area map. Colored symbols indicate springs sampled for this study and grey circles represent springs along the Big Springs Fault. Black dots represent collapse features, red dots indicate breccia pipes,

be naturally occurring and therefore included in an analysis of "background" concentrations.

\section{Site description}

The Snake Gulch study area is within the Colorado Plateau physiographic province of the Southwestern United States (Fig. 1). Pigeon Spring is located in Snake Gulch, which is a tributary canyon to Kanab Creek (Fig. 2). Permian-age sandstone, shale, and limestone layers have been incised in Snake Gulch, with exposed rock units in the canyon wall including the Esplanade Sandstone, Hermit Shale, Coconino Sandstone, Toroweap Formation, and the Kaibab Formation (Fig. 3; Billingsley et al. 1983). Sedimentary rocks in Snake Gulch dip 2-4 ${ }^{\circ}$ to the west-northwest (Billingsley et al. 2008). The plateau surface between Pigeon Mine and Pigeon Spring is about 1,675 $\mathrm{m}$ amsl, with the Snake Gulch canyon floor about $225 \mathrm{~m}$ below. At the east end of Snake Gulch, the Muav and Big springs faults displace strata down to the west from the Kaibab Plateau as much as $366 \mathrm{~m}$ (Billingsley et al. 2008). Snake Gulch cuts into the Esplanade Sandstone where it joins with Kanab Creek. Jumpup Canyon drains into Kanab Creek parallel to the lower part of Snake Gulch and a spring and pink lines indicate folds, and black lines represent normal faults (dashed where approximate; Billingsley et al. 2008)

sediment sample from Upper Jumpup Spring was included in this study because of the similar geologic setting.

Solution-collapse features known as breccia pipes are found throughout this region of Arizona, including within the Snake Gulch study area (Fig. 2). Breccia pipes are thought to form by dissolution and karst development in the underlying Mississippian Redwall Limestone rock unit, with progressive collapse moving upwards through time into overlying rock units, forming a rubble (breccia) filled column that can be as much as $1,000 \mathrm{~m}$ or more in height (Alpine and Brown 2010; Fig. 3). Breccia pipes are roughly circular in plan view, about $100 \mathrm{~m}$ in diameter, and are often characterized by inward dipping beds along the margins (Otton and Van Gosen 2010). Other collapse features found in the Snake Gulch area and throughout the Grand Canyon Region include sinkholes in the Kaibab and Toroweap formations and local and shallow collapse caused by dissolution of gypsum in the Kaibab and Toroweap formations (Billingsley et al. 2008). In absence of breccia at the surface, the most effective way to determine if a breccia pipe underlies a collapse is by drilling.

Some breccia pipes contain concentrated deposits of uranium, copper, silver, lead, zinc, cobalt, and nickel minerals (Wenrich 1985; Wenrich et al. 1989; Finch et al. 1992). 


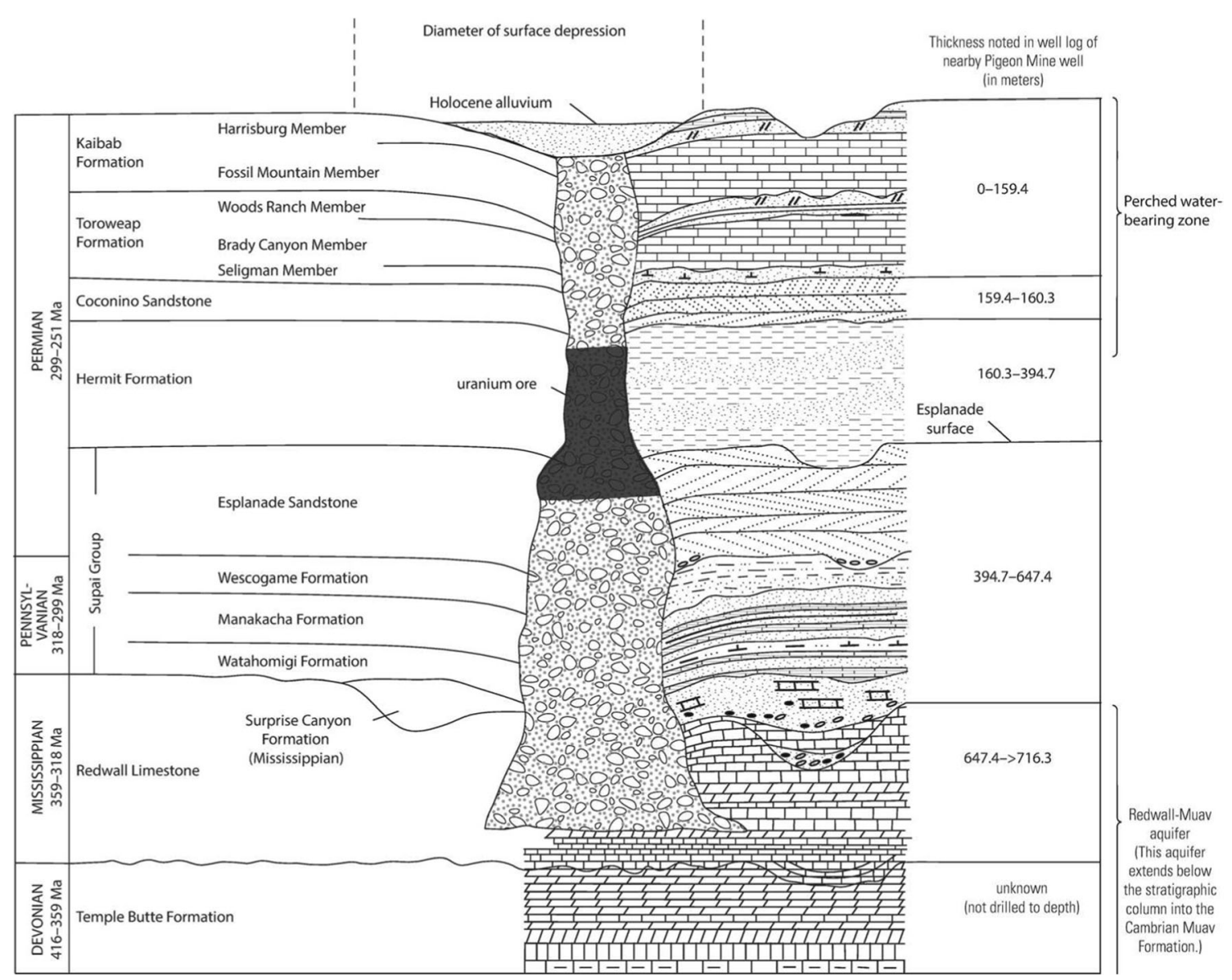

Fig. 3 Stratigraphic section representation of the Pigeon Mine breccia pipe, modified from Van Gosen and Wenrich 1989

Uranium mineralization in breccia pipes likely occurred after previous episodes of mineralizing fluids moving through the pipe which created reducing conditions within areas of the pipe that allowed for uraninite deposition (Wenrich 1985; Huntoon 1996). Mining of breccia pipes for copper, lead, zinc, and silver in the Grand Canyon region began in the 1860s, with uranium mining beginning in the 1950s. The Pigeon breccia pipe (Pigeon Pipe) was discovered in 1980 and the Pigeon Mine began extraction of uranium in 1984 (Otton et al. 2010). Mining was complete by late 1989 and the site was then reclaimed. About 2.6 million $\mathrm{kg}$ of uraninite $\left(\mathrm{U}_{3} \mathrm{O}_{8}\right)$ were extracted from Pigeon Mine from ore located in the breccia pipe in a similar stratigraphic horizon as Hermit Formation and Supai Group (Fig. 3).

The climate in the study area is semiarid to arid with temperature decreasing and precipitation increasing with increasing elevation. Average annual temperature at Page, AZ was $15.4{ }^{\circ} \mathrm{C}$ for January 1997 through December 2008 (Western Regional Climate Center 2016). Freezing winter temperatures are common on the Kaibab Plateau and summer temperatures may exceed $38{ }^{\circ} \mathrm{C}$ in the inner canyons of the area. Average annual precipitation ranges from 500 to $800 \mathrm{~mm}$ on the Kaibab Plateau to less than $300 \mathrm{~mm}$ in the Kanab Creek canyon (PRISM Climate Group 2015). The ratio of annual evaporation to precipitation is about 2:1 in the higher altitudes on the Kaibab Plateau and as much as 5:1 at lower elevations near Snake Gulch (Alpine and Brown 2010; PRISM Climate Group 2015; Farnsworth et al. 1982). Groundwater in the area occurs in locally perched aquifers of limited extent and in the deeper regional Redwall-Muav aquifer, which is several hundred meters below the perched groundwater (Fig. 3). The perched water-bearing zone in the Snake Gulch area is probably recharged by a combination of local precipitation and precipitation falling on the elevated portion of the Kaibab plateau to the east of the study area, which has the highest recharge potential in the area (Flint and Flint 2007). Groundwater in the perched system discharges at several springs in the Snake Gulch area or may migrate deeper into the subsurface (Bills et al. 2010). The direction of groundwater flow in the perched and regional groundwater systems was not previously well defined in the study area, owing to limited potentiometric surface data.

\section{Materials and methods}

Water samples were collected from nine spring sites between August 2009 and August 2015. Five sites (Pigeon, Rock, 
Slide, Upper Jumpup, and Willow springs) were sampled more than one time during the sampling period. Water samples were collected following standard US Geological Survey protocols - US Geological Survey (variously dated). Field parameters including $\mathrm{pH}$, water temperature, specific conductance, dissolved oxygen, and barometric pressure were measured at the spring site just before the water sample was collected. Spring discharge was measured by using volumetric techniques. Water samples were filtered $(0.45 \mu \mathrm{m})$ for major cations, trace and rare earth elements, alkalinity, carbon-14, uranium, radium and strontium isotopes, and all, except for the alkalinity and carbon- 14 samples, were preserved to $\mathrm{pH}<2$ by using ultrapure nitric acid. Unfiltered samples were collected for major anions, tritium, and stable isotopes. Alkalinity titrations using the incremental equivalence method were performed within $5 \mathrm{~h}$ of sample collection-US Geological Survey (variously dated).

Water samples were analyzed for major, trace, and rareearth elements by the USGS National Research Program Laboratory in Boulder, Colorado. Inductively coupled plasma-mass spectrometry (ICP-MS) is used for the following elements; Al, As, B, Ba, Be, Bi, Cd, Ce, Co, Cr, Cs, Cu, Dy, Er, Eu, Ga, Gd, Ho, La, Li, Lu, Mn, Mo, Nd, Ni, P, Pb, Pr, Rb, Re, Sb, Se, Sm, Sn, Sr, Tb, Te, Th, Ti, Tl, Tm, U, V, W, Y, Yb, Zn, and Zr (Garbarino and Taylor 1996; Taylor 2001). Inductively coupled plasma optical emission spectrophotometer (ICP-OES) is used for the following elements; $\mathrm{Ca}, \mathrm{Cr}$, Fe, $\mathrm{K}, \mathrm{Mg}, \mathrm{P}, \mathrm{S}, \mathrm{SiO}_{2}$, and $\mathrm{Ti}$ (Garbarino and Taylor 1979). Anions $\mathrm{Cl}, \mathrm{F}, \mathrm{NO}_{3}$ and $\mathrm{SO}_{4}$ were analyzed by ion chromatography. Samples were analyzed in triplicate and the average is used for the final value. The precision for all methods analyzed by the USGS National Research Program Laboratory in Boulder, Colorado was $4 \%$ or better depending on the element.

Stable isotope ratios $\left(\delta^{18} \mathrm{O}\right.$ and $\left.\delta^{2} \mathrm{H}\right)$ were measured at the USGS Reston Stable Isotope Laboratory (following methods by Révész and Coplen 2008a, b), the 2-sigma uncertainties are $0.2 \%$ o for oxygen and $2 \%$ o for hydrogen isotopic ratios reported relative to Vienna Standard Mean Ocean Water. Strontium isotope ratios $\left({ }^{87} \mathrm{Sr} /{ }^{86} \mathrm{Sr}\right)$ were measured by the USGS National Research Program Laboratory in Menlo Park, California by using methods described in Bullen et al. 1996 and are precise to 0.00002 or better at the $95 \%$ confidence level. Tritium was measured at the USGS Menlo Park Tritium Lab using the electrolytic enrichment liquid scintillation counting method with a detection limit of $0.3 \mathrm{pCi} / \mathrm{L}(0.09$ $\mathrm{TU}$, tritium units).

Multiple laboratories were used to analyze the ${ }^{234} \mathrm{U}^{238} \mathrm{U}$ activity ratio (UAR). The USGS National Research Program Laboratory in Reston, Virginia analyzed UAR by methods described in Kraemer et al. 2002 for samples of Wildband, Pigeon, Rock, Slide, Willow, and Upper Jumpup springs collected between 2009 and 2012. Uranium isotopes $\left({ }^{234} \mathrm{U},{ }^{235} \mathrm{U}\right.$, and ${ }^{238} \mathrm{U}$ ) were measured using method ASTM D 3972 by Eberline Services in Richmond, California for samples from Rock and Slide springs in 2011 and Wildband, Pigeon, and Willow springs in 2012; by Test America in Richland, Washington for Pigeon Spring in 2014; and by ALS Environmental in Fort Collins, Colorado for Slide, Upper Jumpup, Horse, Table Rock, and Warm springs in 2015. The values from the two labs for all seven paired samples were similar (differences of 0.002-0.198 UAR values corresponding to $0.1-3.6 \%$ difference). If two UAR values were available, the value from the USGS National Research Program Laboratory was used.

Carbon-14 and carbon-13/12 were analyzed by the National Ocean Sciences Accelerator Mass Spectrometry (NOSAMS) at Woods Hole Oceanographic Institution. Carbon-14 values reported by the NOSAMS as pM were denormalized using Eq. 5 of Plummer et al. 2012 to pmC. NetpathXL was used to compute corrected groundwater ages using model (11) "Revised F\&G solid ex" (Parkhurst and Charlton 2008). Values used in the computation of groundwater age were carbon- 14 values of 0 pmc for carbonate rock and 100 pmc for soil $\mathrm{CO}_{2}$, and assuming $\delta^{13} \mathrm{C}$ values of 0 and $-1.2 \%$ o for carbonate rock and $-22 \%$ o for soil $\mathrm{CO}_{2}$ (Hart et al. 2010).

Sediment and associated leachate samples presented in this report were collected and analyzed according to methods described in Otton et al. 2010. A brief summary of the methods used by Otton et al. 2010 is included next for reference. Solid samples were digested using a mixture of hydrochloric, nitric, perchloric, and hydrofluoric acids, heated to $110^{\circ} \mathrm{C}$ to dryness and redissolved in nitric acid then aspirated into ICP-AES and ICP-MS. Some of the sediment samples were leached using two different solutions: deionized water (DI) equilibrated with the atmosphere to produce a simulated rainwater solution and water containing $300 \mathrm{mg} / \mathrm{L}$ of hydrogen carbonate. Solid samples were sieved to less than $2 \mathrm{~mm}$ then split into $50 \mathrm{-g}$ subsamples and processed according to the Hageman and Briggs Field Leach Test (Hageman and Briggs 2000). The final supernatant liquid following the leach test was filtered and acidified then analyzed for chemical analysis including trace element analysis using ICP-MS (Lamothe et al. 2002). Additional solid and leachate sample data not published in Otton et al. 2010, but analyzed by the same methods, for site PS-08 and ore from the Pigeon Mine are presented in this report.

Principal components analysis (PCA) was used to reduce the complex data structure (many samples and many elements) to a fewer number of principal component vectors. The PCA was used to visualize the trace metal concentrations for sediment and water samples for the following elements As, $\mathrm{Ba}, \mathrm{Cd}, \mathrm{Ce}, \mathrm{Cu}, \mathrm{La}, \mathrm{Li}, \mathrm{Mn}, \mathrm{Mo}, \mathrm{Pb}, \mathrm{Rb}, \mathrm{Sb}, \mathrm{Se}$ (water only), $\mathrm{Sr}, \mathrm{U}, \mathrm{V}, \mathrm{Y}$, and Zn. Data were logarithmically transformed to make the data more normally distributed, and then data were 
normalized or scaled (subtracting the mean and dividing by the variance) prior to computing a Euclidean distance matrix, which is the implicit matrix underlying a PCA analysis (Clarke and Warwick 2001). PCA generates linear combinations of variables that are represented with principal component vectors. The first principal component (PC1) accounts for the greatest proportion of variance in the data and each successive orthogonal component accounts for next greatest proportion of the variance. Contributions from the variables are expressed as loadings where the highest loadings are interpreted as the most significant. Directionality of the loadings ( \pm ) is also interpretable, indicating increasing or decreasing variable values. For elements with values less than the reporting limit, a value of half of the reporting limit was used for the PCA (Antweiler and Taylor 2008).

A cluster analysis was also used to identify similar groups in the spring samples by evaluating minimum differences within groups and maximum differences among groups. The cluster analysis used a simple agglomerative, hierarchical clustering technique with a group average linkage option. A similarity profile (SIMPROF) test was used to statistically evaluate whether or not a specified set of samples, which are not a priori assigned into groups, do not differ from each other in multivariate structure (Clarke and Warwick 2001). SIMPROF is a permutation test that statistically tests different groups $(p \leq 0.05)$ by computing the likelihood that individual groups were not generated purely by chance alone.

PHREEQCI version 3.3.3 (Charlton and Parkhurst 2002; Parkhurst and Appelo 2013) was used to determine geochemical properties of the sampled waters including saturation indices. The WATEQ4F database was used with the default pe value of 4 since none of the water samples indicate reducing conditions.

Potentiometric contours were created in ArcMap 10.3.1 using groundwater elevations from USGS (2015) contoured using natural neighbor interpolation. The lines were then modified so that contour lines were discontinuous across Snake Gulch where the elevation of the bottom of the canyon is deeper than the projected contour line and adjusted on the east side of the map north of Warm Springs to mimic the Muav Fault trace, which likely affects groundwater flow paths. Contour lines are dashed where approximate.

\section{Results and discussion}

This section is organized in three sections: the first presents and discusses water chemistry results, the second considers the groundwater flowpath and residence time of groundwater in a geologic context, and the last discusses potential sources of elevated uranium at Pigeon Spring based on the information presented in the first two sections.

\section{Water chemistry}

Springs sampled for this study were neutral to slightly alkaline, had moderately high specific conductance $(545-2,735 \mu \mathrm{S} / \mathrm{cm})$, contained measurable dissolved oxygen, and temperatures that varied depending on the time of year the sample was collected (Table 1) for example temperature in the Pigeon Spring pool ranged from $8.3^{\circ} \mathrm{C}$ in March, $20^{\circ} \mathrm{C}$ in September, and $11.8^{\circ} \mathrm{C}$ in November. Spring discharge varied across the study area where several springs were slow seeping springs and others such as Slide and Warm springs had much higher flow rates.

Water type for the majority of the springs in Snake Gulch is calcium sulfate-Fig. S1 of the electronic supplementary material (ESM). Slide, Horse, and Upper Jumpup springs were calcium-magnesium sulfate type waters. These three springs discharge at the southeastern end of the study area. Warm Spring was a calcium-magnesium hydrogen carbonatesulfate water and was the only spring included in this study which discharges upgradient of Snake Gulch and of the Big Springs Fault.

Saturation indices for spring samples were calculated using PHREEQC where negative values indicate undersaturation with respect to that mineral phase and positive values indicate oversaturation; values near zero may indicate minerals that react to equilibrium. The Kaibab Formation is composed of gypsiferous siltstones, sandstone, gypsum, limestone, sandy and cherty limestone; the Toroweap Formation is composed of gypsiferous siltstone, silty sandstone, gypsum, limestone and sandy limestone; the Coconino Sandstone is a fine-grained quartz sandstone and the Hermit Formation is composed of calcareous sandstone and siltstone (Billingsley et al. 2008). Gypsum dissolution is likely contributing to the calcium and sulfate ion composition of most of the springs. The saturation index for gypsum was negative $(-0.1$ to -0.94$)$ for nearly all spring samples, indicating that the water could still dissolve more gypsum, with the exception of Wildband Spring $(+0.04)$ which indicates sufficient reaction to attain gypsum equilibrium. Wildband Spring also had the highest specific conductance. Most spring waters were near equilibrium or oversaturated with respect to calcite $(+0.04$ to +1.21$)$, indicating that the potential to precipitate calcite. Two samples had negative saturation indices for calcite: Warm Spring $(-0.67)$ and one sample from Upper Jumpup Spring in $2015(-0.81)$. Saturation indices were negative for all uranium minerals included in the PHREEQC simulations (Table S2 of the ESM).

Uranium concentration measured during this study was lowest at Warm Spring $(0.86 \mu \mathrm{g} / \mathrm{L})$ and greatest at Pigeon Spring $(80 \mu \mathrm{g} / \mathrm{L}$ average). The uranium concentrations for many springs in the study area were measured in 1982 before the Pigeon Mine began extracting ore as part of a pre-mining USGS study in the area (Table 2). Uranium concentrations at three springs increased in concentration between 1982 and the samples collected in this study starting in 2009 , where the 
Table 1 Site characteristics and water-quality parameter values for springs in the Snake Gulch study area. $N M$ not measured

\begin{tabular}{|c|c|c|c|c|c|c|c|}
\hline Spring name & Rock unit & $\begin{array}{l}\text { Elevation } \\
\text { (m asl) }\end{array}$ & $\begin{array}{l}\text { Discharge } \\
\text { (L/min) }\end{array}$ & $\begin{array}{l}\text { Temperature } \\
\left({ }^{\circ} \mathrm{C}\right)\end{array}$ & $\mathrm{pH}$ & $\begin{array}{l}\text { Specific } \\
\text { conductance } \\
(\mu \mathrm{S} / \mathrm{cm})\end{array}$ & $\begin{array}{l}\text { Dissolved } \\
\text { oxygen } \\
(\mathrm{mg} / \mathrm{L})\end{array}$ \\
\hline Pigeon (3) & Toroweap Formation & 1512 & 0.23 & 13.4 & 7 & 2,667 & 3.7 \\
\hline Table Rock & Toroweap Formation & 1609 & $\mathrm{NM}$ & 17.9 & 7.75 & 1,447 & 7.7 \\
\hline Wildband & Toroweap Formation & 1548 & 1.14 & 15 & 8.3 & 3,250 & 9.4 \\
\hline Willow (2) & Coconino Sandstone & 1451 & 3.56 & 11.6 & 8.1 & 2,735 & 8.8 \\
\hline Rock (2) & Hermit Formation & 1329 & 0.42 & 19 & 7.6 & 2,490 & 7.6 \\
\hline Slide (3) & Coconino Sandstone & 1487 & 238 & 15.6 & 7.5 & 1,157 & 5.7 \\
\hline Horse & Coconino Sandstone & 1481 & $\mathrm{NM}$ & 18.2 & 7.5 & 1,250 & 7.3 \\
\hline Upper Jumpup (2) & Coconino Sandstone & 1553 & 4.92 & 13.4 & 7 & 864 & 6.7 \\
\hline Warm & Coconino Sandstone & 2195 & 14.4 & 11.4 & 7 & 545 & 8.5 \\
\hline
\end{tabular}

Numbers in italic indicate an average value from samples collected at different times (number of samples in parenthesis next to spring name)

percent increase for the springs ranged from 66 to $109 \%$ for Pigeon Spring, $80-87 \%$ for Slide Spring and $40-80 \%$ for Willow Spring. The increase in concentration at these springs may be due to differences in sample collection, analysis, seasonal effects or changes in the system. Pigeon Spring had the greatest uranium concentration of springs in Snake Gulch in 1982 (Hopkins et al. 1984) and also had the greatest concentration in springs sampled in 2012-2014. For Snake Gulch, Billingsley et al. 1983 defined concentrations of uranium in the range of $1-9 \mu \mathrm{g} / \mathrm{L}$ to be background, $10-40 \mu \mathrm{g} / \mathrm{L}$ to be weakly anomalous and $>40 \mu \mathrm{g} / \mathrm{L}$ to be strongly anomalous. Using these criteria, Rock and Willow springs had weakly anomalous concentrations of uranium in 2009-2012 (averages of 15 and $16 \mu \mathrm{g} / \mathrm{L}$ respectively), and Pigeon Spring had strongly anomalous concentrations. Wildband had weakly anomalous concentrations in $1982(10 \mu \mathrm{g} / \mathrm{L})$ and background in $2012(8.7 \mu \mathrm{g} / \mathrm{L})$.

Evidence for uranium mobility can be determined from geochemical conditions and uranium isotopes. Conditions that favor uranium mobility in groundwater are presence of detectible dissolved oxygen and dissolved inorganic carbon. Waters from this study all had measurable dissolved oxygen and dissolved inorganic carbon primarily present as hydrogen carbonate. The isotopic composition of uranium in groundwater can be used to evaluate the proximity of the uranium source. Natural uranium consists of three isotopes ${ }^{238} \mathrm{U},{ }^{235} \mathrm{U}$, and ${ }^{234} \mathrm{U}$ with relative abundances of approximately $99.27,0.72$, and $0.0057 \%$, respectively. The ${ }^{235} \mathrm{U} /{ }^{238} \mathrm{U}$ ratio exhibits an extremely small range of variation in nature $(0.05-0.11$ from springs in this study), but ${ }^{234} \mathrm{U} /{ }^{238} \mathrm{U}$ can vary widely and values can be greater than 1 due to alpha recoil where during alpha decay of ${ }^{238} \mathrm{U}$ the recoiling ${ }^{234} \mathrm{Th}$ nuclei can be ejected from the solid to aqueous phase and then decay to ${ }^{234} \mathrm{U}$ with typical values in natural waters between 1 and 3, and values greater than 10 have been reported (Kronfeld 1974; Osmond and Cowart 1976; Szabo 1982). Uranium in undisturbed rocks and minerals older than approximately 1 million years, reaches a state of radioactive equilibrium (or secular equilibrium) where the rate of decay of ${ }^{234} \mathrm{U}$ is limited by the rate of decay of ${ }^{238} \mathrm{U}$, and the UAR approaches 1 ; uranium mineralization in the breccia pipes of the area likely occurred between 141 and 200 million years ago (Wenrich 1985). Bulk
Table 2 Uranium $(U)$ concentrations from springs in the study area, values in micrograms per liter

\begin{tabular}{lllll}
\hline Spring name & $\begin{array}{l}\text { U, 1982 sample } \\
\text { (Hopkins et al. 1984) }\end{array}$ & $\begin{array}{l}\text { U, 1st recent } \\
\text { sample }\end{array}$ & $\begin{array}{l}\text { U, 2nd recent } \\
\text { sample }\end{array}$ & $\begin{array}{l}\text { U, 3rd recent } \\
\text { sample }\end{array}$ \\
\hline Pigeon & 44 & 92 (Mar-12) & 74 (Nov-12) & 73 (Sept-14) \\
Table Rock & 5.2 & 6.6 (Aug-15) & - & - \\
Wildband & 14 & 8.7 (Nov-12) & - & - \\
Willow & 10 & 14 (Mar-12) & 18 (Nov-12) & - \\
Rock & 15 & 14 (Sept-09) & 16 (Aug-11) & - \\
Slide & 1.5 & $2.8($ Aug-09) & 2.7 (Jul-11) & 2.8 (Aug-15) \\
Horse & - & 3.7 (Aug-15) & - & - \\
Upper Jumpup & - & 3.9 (Aug-09) & $3.8($ Jul-15) & - \\
Warm & - & 0.86 (Aug-15) & - & - \\
\hline
\end{tabular}

Month and year of recent samples are noted in parentheses 
dissolution of the solid phase uranium in breccia pipes in a chemically aggressive environment (e.g., fresh mill tailings or fresh exposures of ore) results in the release of uranium that has an isotopic composition similar to that of the rock (i.e., a UAR value close to 1.0). Water in contact with high-grade uranium ore that has a recent history of oxidation and leaching are a mix of material with UARs both greater than and less than 1.0 (Cowart and Osmond 1977).

Pigeon Spring had the lowest UAR (average of 1.41) of all springs from this study. Pigeon Spring was most similar to a group of springs - Table Rock, Wildband, Willow, and Rock springs - in the center of the study area that also had low UAR values (1.8-2.4). Springs on the south end of the study area, Upper Jumpup, Horse, and Slide springs, had greater UAR values from 4.52 to 5.59 (Fig. 4). There is a general correlation of lower UAR values associated with greater values of uranium, which may indicate a more direct dissolution of uranium minerals for springs with lower UAR values.

The stable isotopes of oxygen and hydrogen can give a general indication of recharge elevation and evaporation. A local meteoric water line (LMWL) of $\delta^{2} \mathrm{H}=7.4 \delta^{18} \mathrm{O}+6.5$ was developed for Grand Canyon National Park at Hopi Point (Pendall 1997), which plots to the left of the global meteoric water line (GMWL; Craig 1961; Fig. 5). Warm Spring isotopic ratio plots on the GMWL and is the most depleted of all of the spring samples $(-13.26,-96.8)$, indicating that the water discharging at Warm Spring recharged at a distinctly higher elevation or from colder a climate compared to the other springs and that the water has not undergone much evaporation. Wildband Spring had the most enriched isotopic value $(-9.61,-79.8)$ and plots far to the right of the GMWL indicating that the water has undergone significant evaporation. The other spring samples fall within a smaller range $(-12.23$ to $-11.71,-91.2$ to -85.56$)$ and all plot to the right of the GMWL indicating that the waters have undergone some evaporation and were recharged from a similar elevation (Fig. 5). Soil water near Red Butte, AZ (just south of the Grand Canyon) plotted to the right of the LMWL indicating evaporation influence (Pendall 1997), so it is unclear whether the evaporation signature of the spring groundwater samples occurs during groundwater infiltration or after spring discharge.

Strontium isotope ratios provide an understanding of rock types a groundwater has interacted with along its flowpath. The strontium isotope ratios fell within a narrow range (0.70774-0.70796) for most of the springs in the area with the exception of Pigeon and Table Rock springs (0.70852 and 0.70834; Fig. 6). Average strontium isotope ratios for the Kaibab Formation is 0.70811 and Toroweap Formation is 0.70831 from samples near the south rim of the Grand Canyon and well cuttings near Williams, AZ (Monroe et al. 2005; Bills et al. 2007). Pigeon and Table Rock Spring waters have values greater than these two rock ratios, while the other springs have water with lower values than the Kaibab Formation strontium isotope ratio. The Coconino Sandstone and Hermit Formation have greater average values (0.70989 and 0.71013; Monroe et al. 2005; Bills et al. 2007). The isotope ratios from the springs do not indicate much interaction with these units, rather more interaction with the Toroweap and Kaibab
Fig. 4 Uranium activity ratio (UAR) values relative to $1 /$ uranium concentration for spring samples

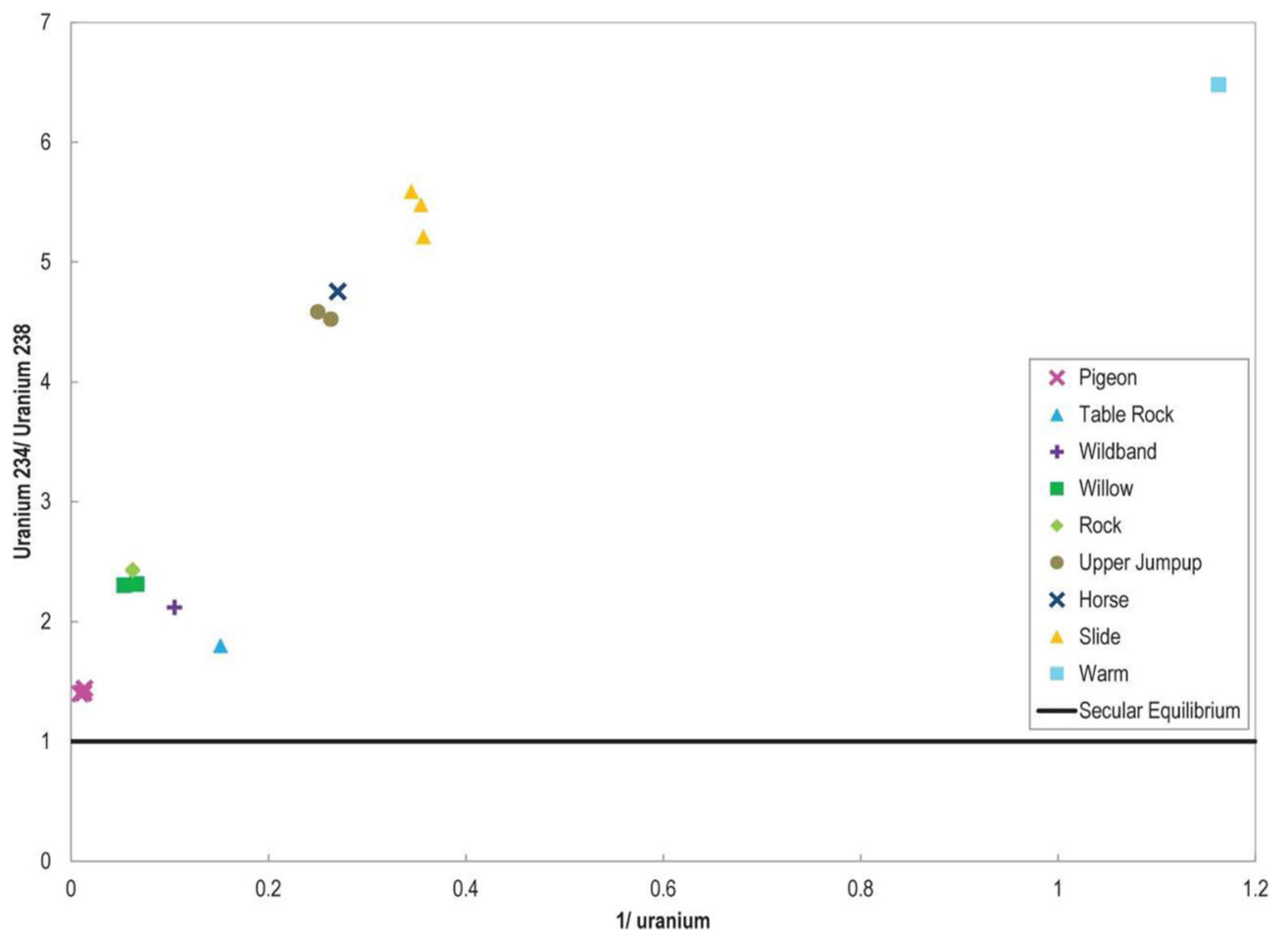


Fig. 5 Stable isotope ratios $\left(\delta^{18} \mathrm{O}\right.$ and $\delta^{2} \mathrm{H}$ ) for spring samples.

Global meteoric water line (GMWL) from Craig (1961) and local meteoric water line $(L M W L)$ from Pendall (1997)

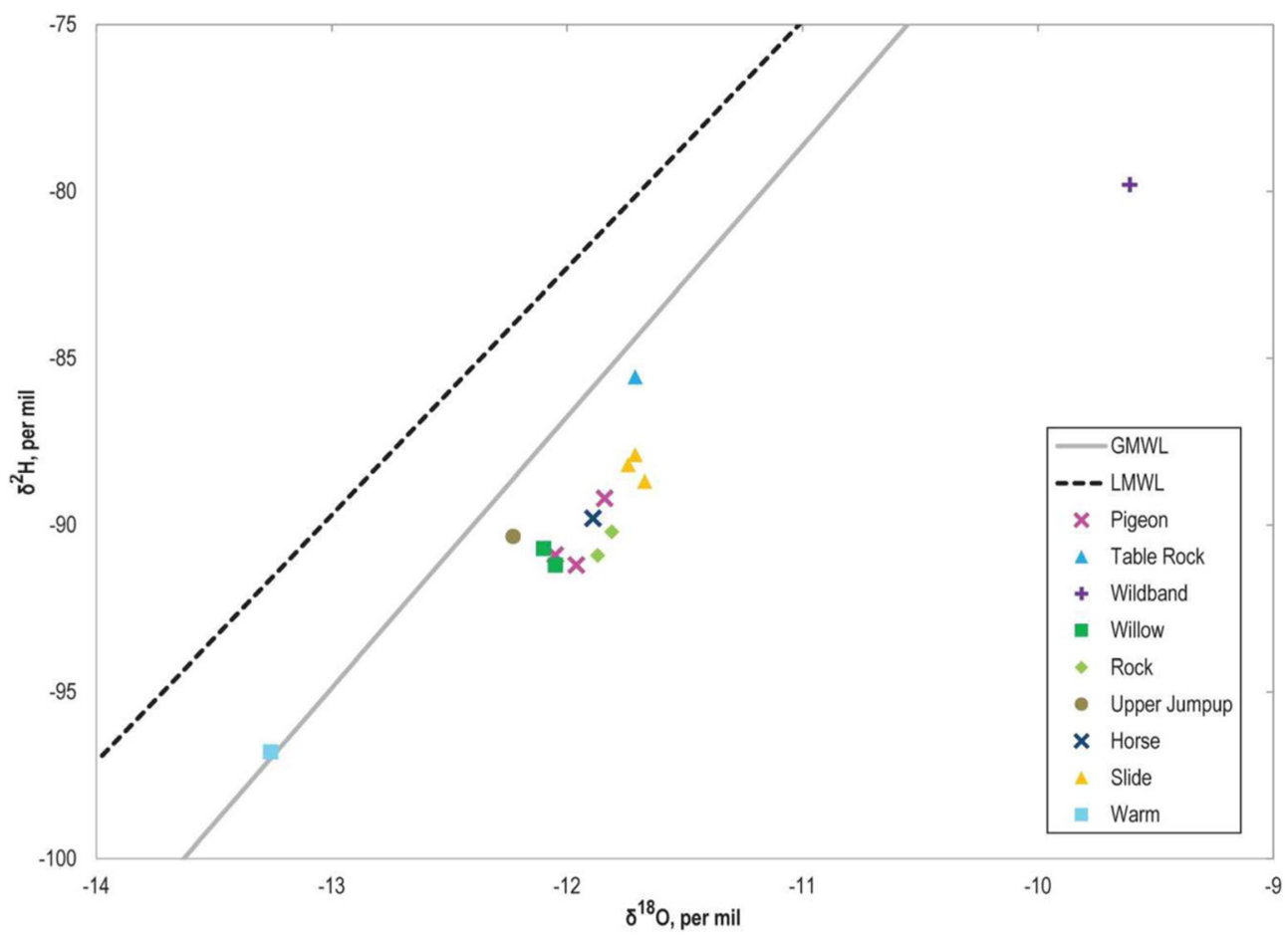

Formations. There was some variation in the strontium isotopic values, as shown by the minimum and maximum values for each unit on Fig. 6, of the Kaibab Formation, Coconino Sandstone, and Hermit Formation in the data from Monroe et al. (2005) and Bills et al. (2007), so additional analysis of strontium isotopic values in rock units from this study area would help with the interpretation of the rock units that the groundwater interacted with.

\section{Groundwater flowpaths and residence times}

The majority of modern recharge in the study area occurs on the uplifted area of the Kaibab Plateau, which reaches an elevation of $2,817 \mathrm{~m}$ (Figs. 1 and 7). Average annual precipitation ranges from 500 to $800 \mathrm{~mm}$ on the elevated Kaibab Plateau to less than $300 \mathrm{~mm}$ in the Kanab Creek canyon (PRISM Climate Group 2015). The Big Springs and Muav Faults displace the
Fig. 6 Strontium isotope ratio relative to 1 /strontium concentration for spring samples; values from rock samples in Bills et al. 2007 and Monroe et al. 2005

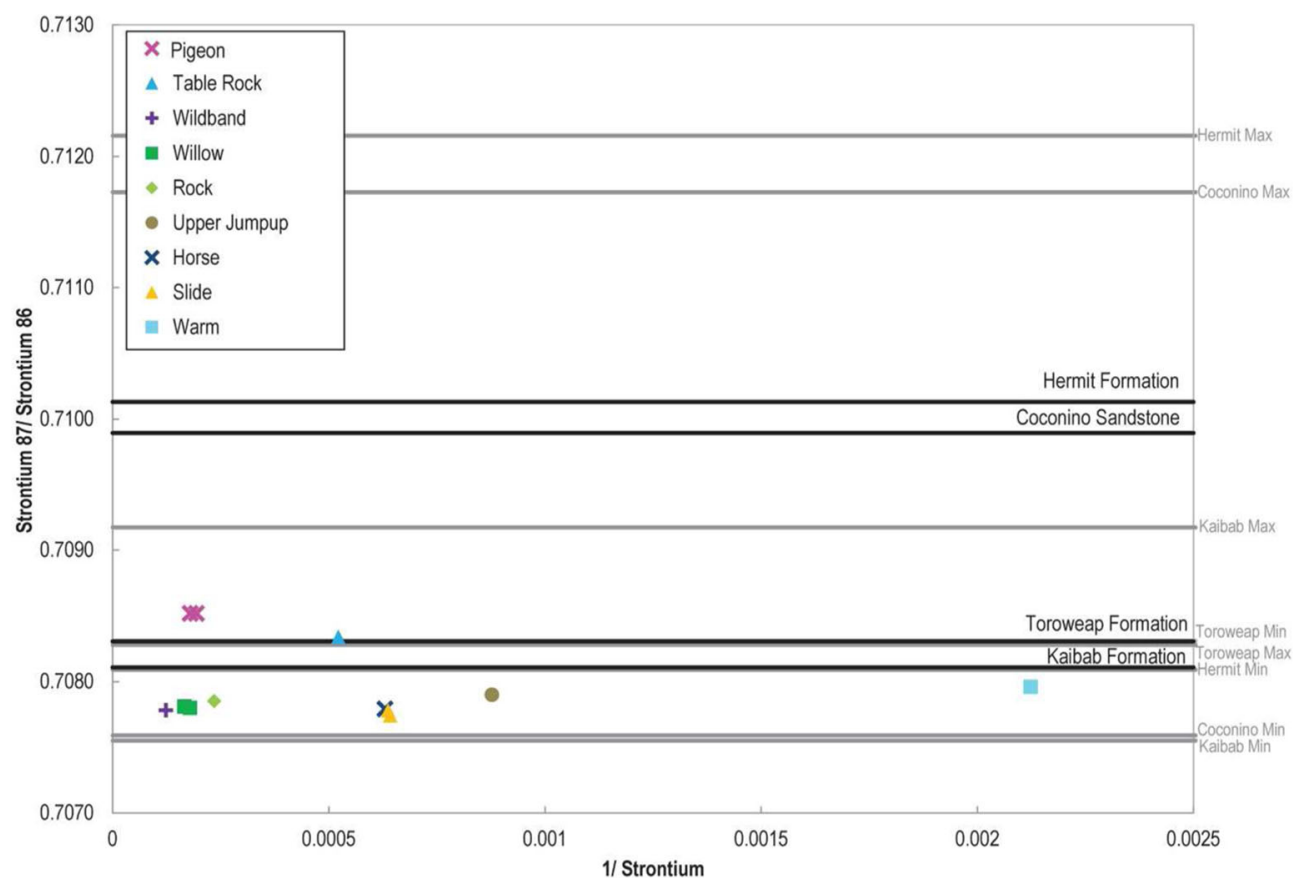




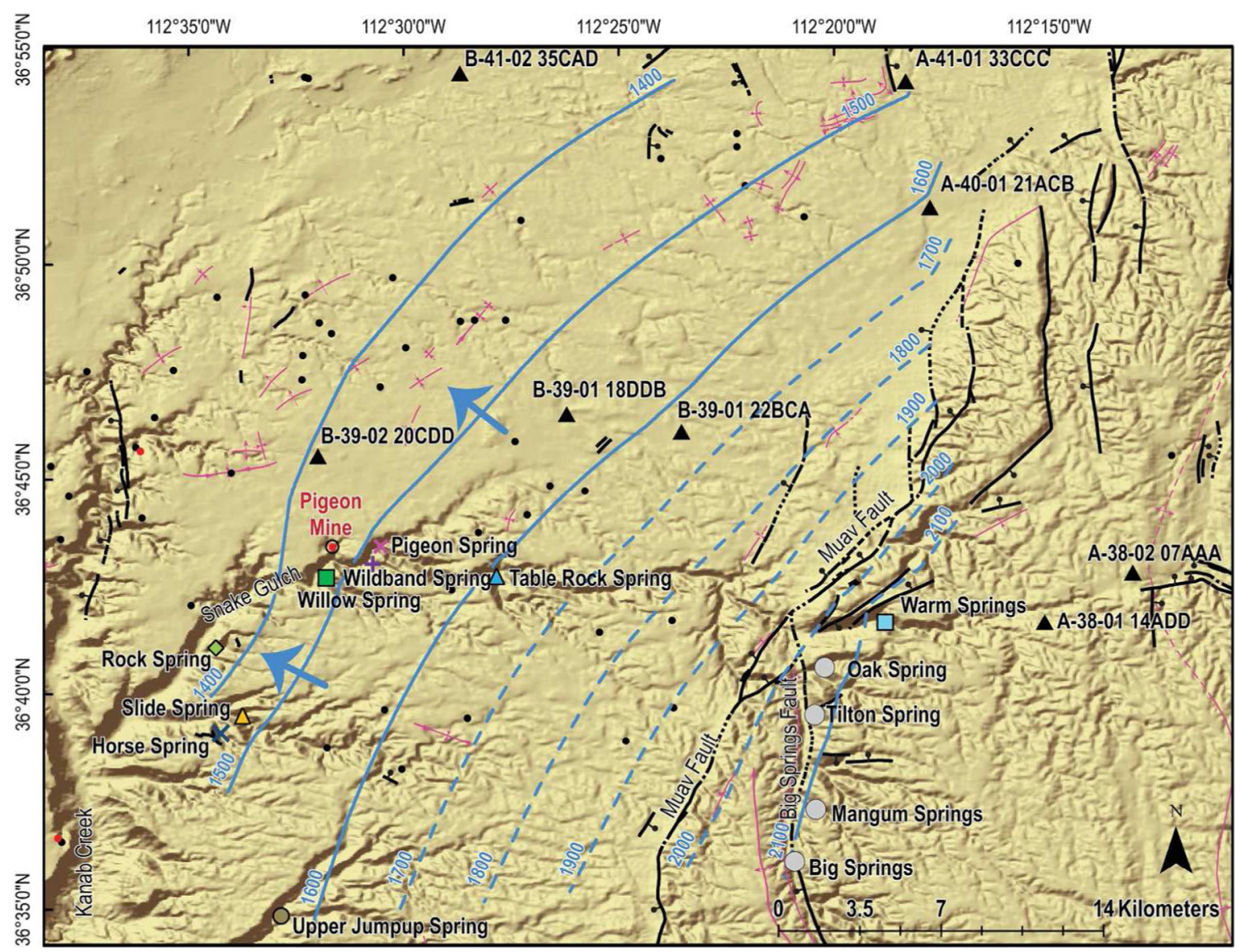

Fig. 7 Potentiometric perched groundwater surface contours in meters amsl, dashed where approximate. Colored symbols indicate springs sampled for this study and grey circles represent springs along the Big

uplifted area of the Kaibab Plateau from the western portion of our study area including Snake Gulch. Several springs discharge along the Big Springs Fault (Warm, Oak, Tilton, Mangum and Big springs); however, there is no perennial surface water flowing away from these springs, which indicates that the water discharging at the springs may then reinfiltrate into the subsurface. Some of the reinfiltrated water may move west and or some may move south along the Big Springs Fault.

The groundwater potentiometric surface generated for the study area indicates that groundwater is generally moving toward the west-northwest in the area south of Snake Gulch and to the northwest in the area north of Snake Gulch (Fig. 7). The Harrisburg Member of the Kaibab Formation is dipping between 2 and $5^{\circ}$ to the northwest to the west of the Muav fault (Billingsley et al. 2008). The potentiometric surface shows groundwater flow to be moving in a similar direction to the dip of the surface rocks of the Kaibab Formation. Pigeon Spring discharges from a south facing canyon wall in Pigeon Canyon before it merges with Snake Gulch. Gettings and Bultman (2005) show magnetic and gravity geophysical evidence of a fracture network along Pigeon Canyon trending towards the northeast that may provide a preferential pathway for perched water to flow towards Pigeon Spring as well as a
Springs Fault. Black dots represent collapse features, red dots indicate breccia pipes, pink lines indicate folds, and black lines represent normal faults (dashed where approximate; Billingsley et al. 2008)

potential conduit for precipitation to enter the groundwater system. The Muav Fault has offsets of 24-110 m before merging with the Big Springs Fault (146 m offset south of Big Springs) after which the Muav fault has $366 \mathrm{~m}$ of offset then 61 and $37 \mathrm{~m}$ of offset as the fault continues to the north (Billingsley et al. 2008). The Muav and Big springs Fault cut into the Hermit Formation at land surface just north of Mangum Springs (Fig. 7; Billingsley et al. 2008). The springs in Snake Gulch emerge from units including the Hermit Formation and younger units, and movement of water in these units across the Muav and Big Springs faults would be offset from the area of greatest recharge on the Kaibab Plateau. Slide Spring is the largest discharging spring in this study and according to the flowpath determined from the potentiometric contours groundwater moving towards this spring would cross the Muav and Big Springs faults in an area where the Hermit Formation was not exposed at the surface and may also be controlled by fracture networks presented in Gettings and Bultman 2005 (Fig. 7).

Pigeon, Wildband, Willow, and Rock springs were sampled for tritium, and ranged from 0.25 to 0.59 TU. Upper Jumpup, Slide and Horse springs had low tritium values (0$0.11 \mathrm{TU})$. Values of tritium peaked during the period of 
nuclear bomb testing in the 1950s and 1960s and then decreased over the next decades. In recent precipitation (after 1992), tritium values have stopped decreasing, and average values of tritium in precipitation range from 5.1 TU in Camp Verde to 8.9 TU in Flagstaff (Eastoe et al. 2012). The tritium data indicate that the groundwater present at the spring sites was either primarily recharged in the decades prior to 1952 (submodern) or is a mixture of post bomb pulse and tritium dead water. Using the laboratory detection limit of $0.09 \mathrm{TU}$ and an initial tritium value of $8.9 \mathrm{TU}$ from Flagstaff, AZ, water with detectable tritium could have been recharged 82 years prior to sample collection. Therefore, the presence of detectable tritium indicates that there is some component of water recharged after 1932 for samples collected in 2014.

Groundwater age is interpreted using carbon-14 with corrections based on dissolved inorganic carbon (hydrogen carbonate) and $\delta^{13} \mathrm{C}$. Graphs of carbon species were made according to Han et al. (2012) and Han and Plummer (2016) to understand the potential processes influencing carbon water chemistry at the spring sample sites before interpretation of groundwater age (Fig. 8). The dark lines on Fig. 8 represent the zero age lines, which are determined by the carbon-14 and $\delta^{13} \mathrm{C}$ values of the soil gas and solid carbonate. Samples that plot within the zero age lines on Fig. 8a have zero radiocarbon age, samples above the zero age area are likely mixtures containing some carbon-14 recharge water, samples below the zero age line on Fig. 8 may have radiocarbon age greater than zero (Han and Plummer 2016). Samples from Wildband and Willow springs indicate that the sample may have undergone loss of $\mathrm{CO}_{2}$ gas (Fig. 8). Wildband and Willow springs were the only two samples collected as spring water flowed over a rock face and fell into the sample container, which could have allowed time for loss of $\mathrm{CO}_{2}$ gas from the sample or reequilibration with the surrounding atmospheric $\mathrm{CO}_{2}$ (Han et al. 2012). Because of the potential changes to carbon water chemistry occurring before sampling, quantification of groundwater age was not conducted for these two springs. Samples from Rock, Table Rock, and Warm springs indicate that the waters could have undergone dedolomitization characterized by the dissolution of dolomite $\left[\mathrm{CaMg}\left(\mathrm{CO}_{3}\right)_{2}\right]$ and gypsum $\left(\mathrm{CaSO}_{4}\right)$ enriched in $\delta^{13} \mathrm{C}$ or could be explained by calcite $\left(\mathrm{CaCO}_{3}\right)$ precipitation (Fig. 8b, c; Han et al. 2012).

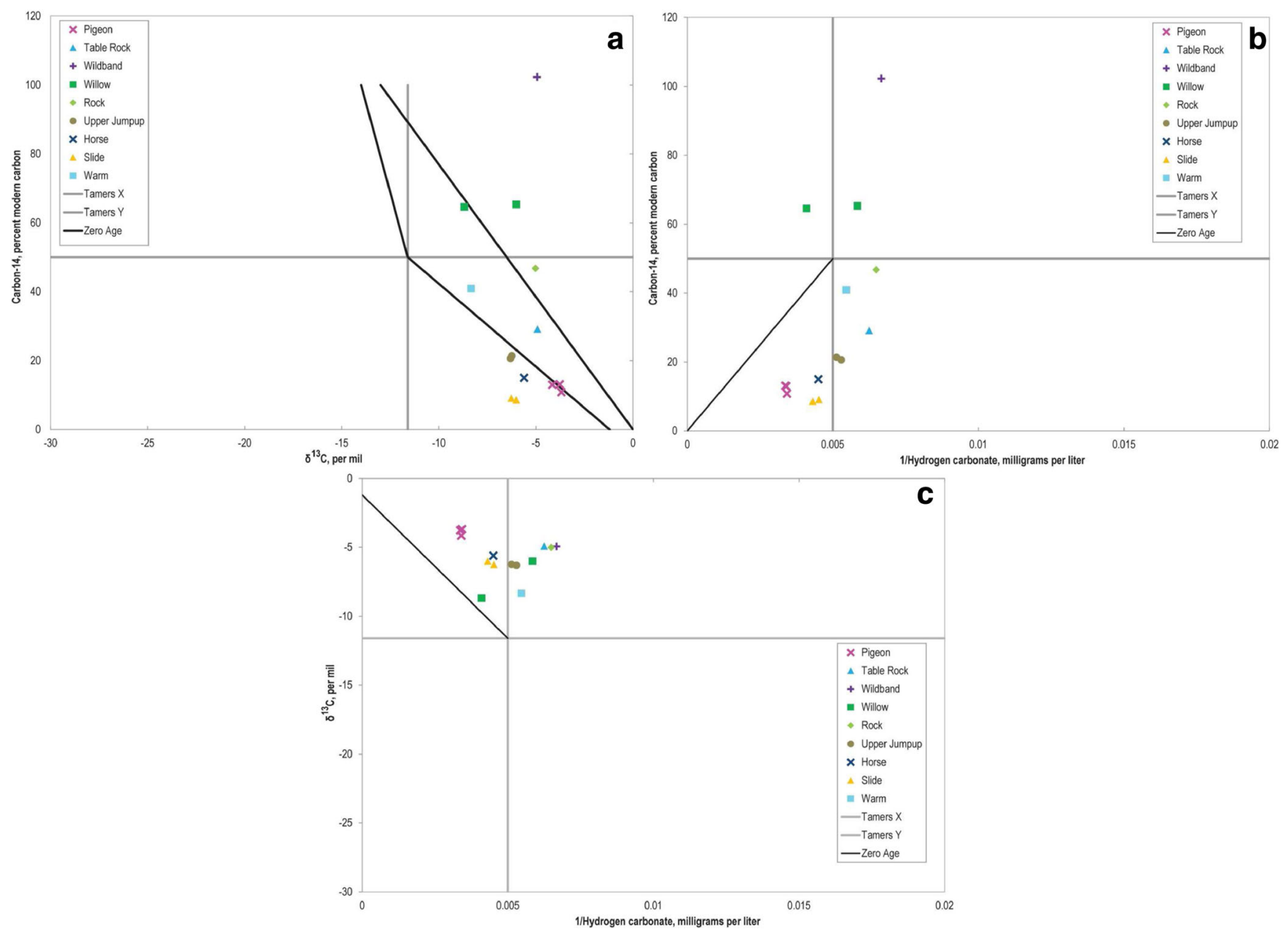

Fig. 8 Carbon data from spring water. a Carbon- 14 versus $\delta^{13} \mathrm{C}$, b Carbon-14 versus $1 /$ hydrogen carbonate, and $\mathbf{c} \delta^{13} \mathrm{C}$ versus $1 /$ hydrogen carbonate. The dark lines represent the zero age lines, which are determined by the carbon-14 and $\delta^{13} \mathrm{C}$ values of the soil gas and solid carbonate 
Samples from Pigeon, Upper Jumpup, Horse, and Slide springs plot in the region indicating that they may be old waters that could have undergone ${ }^{14} \mathrm{C}$ decay (Fig. 8; Han et al. 2012). Upper Jumpup Spring plots near the threshold for waters that could have undergone dedolomitization characterized by the dissolution of dolomite and gypsum enriched in $\delta^{13} \mathrm{C}$ or could be explained by calcite $\left(\mathrm{CaCO}_{3}\right)$ precipitation on plots including hydrogen carbonate (Fig 8b, c; Han et al. 2012).

Values used in the computation of groundwater age of Pigeon, Upper Jumpup, Horse, and Slide Spring using NetpathXL (Parkhurst and Charlton 2008) were carbon-14 values of $0 \mathrm{pmc}$ for carbonate rock and $100 \mathrm{pmc}$ for soil $\mathrm{CO}_{2}$, and assuming $\delta^{13} \mathrm{C}$ values of $0 \%$ o for carbonate rock and $-22 \%$ for soil $\mathrm{CO} 2$ (Hart et al. 2010). $\delta^{13} \mathrm{C}$ for the rock units Kaibab, Toroweap and Hermit formations are $-1.0,-1.4$ and $-1.3 \%$ respectively from rocks near the south rim of the Grand Canyon and well cuttings near Williams AZ (Bills et al. 2007). The average of the three $\delta^{13} \mathrm{C}$ rock unit values is -1.2 and was also used for the $\delta^{13} \mathrm{C}$ value of carbonate rock in NetpathXL to understand the difference in groundwater age interpretation if the groundwater was interacting with carbonate rock with this carbon isotope signature.

None of the samples fell within the Tamers area (Parkhurst and Charlton 2008; Han and Plummer 2013; Tamers 1967, 1975; Tamers and Scharpenseel 1970), so the results of the Tamers model are not presented. Results from NetpathXL are presented in Table 3 for both values of $\delta^{13} \mathrm{C}$ in carbonate rock and soil gas for the uncorrected age (user-defined), Ingerson and Pearson (Ingerson and Pearson Jr 1964), and Revised Fontes and Garnier (solid exchange; Han and Plummer 2013). Ingerson and Pearson model does not include isotope exchange, it is just isotope dilution for dissolution (Han and Plummer 2016).

The calculated corrected groundwater ages are sensitive to the value of $\delta^{13} \mathrm{C}$ in the soil gas $\mathrm{CO}_{2}$ and carbonate rock, with the oldest ages using $0 \%$ o. Using a value of $-1.2 \%$ o decreases the corrected age for the springs and also results in negative ages for some of the Pigeon Spring samples indicating that the correction methods are not appropriate for calculating the groundwater age or that the sample plots near the zero age line if the carbonate rock is $-1.2 \% \circ \delta^{13} \mathrm{C}$. There was some variation in the $\delta^{13} \mathrm{C}$ data from Bills et al. (2007) where the range of $\delta^{13} \mathrm{C}$ in the Kaibab was -2 to -0.2 ; Toroweap was -1.8 to -1 , and the Hermit was -2.3 to -0.3 , so analysis of $\delta^{13} \mathrm{C}$ in rock units from this study area would help with the interpretation of the age dating of the groundwater for Pigeon, Slide, Horse, and Upper Jumpup springs. A soil gas $\mathrm{CO}_{2}$ value of $-22 \%$ o for $\delta^{13} \mathrm{C}$ was used based on the values from Hart et al. 2010 for $\mathrm{C} 3$ plant dominated areas in Utah. The biome for the majority of the study area is Great Basin Conifer (Arizona Game and Fish 2015) which is dominated by C3 plants and the Great Basin Desert Scrub biome is present in lower elevations on the western side of the study area. The plant communities have been similar for the last 14,040 years BP in the area to the north of the Grand Canyon, which includes the range of corrected groundwater ages (Anderson et al. 2000). Appelo and Postma (2005) report $-27 \%$ ofor $\delta^{13} \mathrm{C}$ of $\mathrm{C} 3$ plants and some arid zone $\mathrm{C} 4$ plants have a heavier $\delta^{13} \mathrm{C}$ value of $-13 \%$ o (Farquhar et al. 1989; Vogel 1993). The $-22 \%$ v value may represent a mixture of $\mathrm{C} 3$ and $\mathrm{C} 4$ plants and provides a good estimation for the age of the groundwater in this study. Soil gas $\delta^{13} \mathrm{C}$ value for the study area would help better constrain the age of the perched groundwater at the sampled springs.

\section{Potential sources of elevated uranium at Pigeon Spring}

The Pigeon Mine was prepared and developed from 1982 to 1984, mining began in 1984 and ended in 1989, and the site has since been reclaimed (Otton et al. 2010). During mine development, perched water was encountered in the mineshaft on the order of $27 \mathrm{~L} / \mathrm{min}$ and was noted to decrease during the beginning of mining production to about $15 \mathrm{~L} / \mathrm{min}$ in 1985

Table 3 Groundwater age in years results from NetpathXL

\begin{tabular}{|c|c|c|c|c|c|c|}
\hline \multirow[t]{2}{*}{ Spring name } & \multirow[t]{2}{*}{ Sample date } & \multirow[t]{2}{*}{ Uncorrected age (years BP) } & \multicolumn{2}{|c|}{$\begin{array}{l}\text { Ingerson and Pearson } \\
\text { (corrected age years BP) }\end{array}$} & \multicolumn{2}{|c|}{$\begin{array}{l}\text { Revised Fontes and Garnier (solid exchange) } \\
\text { (corrected age years BP) }\end{array}$} \\
\hline & & & $0 \delta^{13} \mathrm{C}^{\mathrm{a}}$ & $-1.2 \delta^{13} \mathrm{C}^{\mathrm{a}}$ & $0 \delta^{13} \mathrm{C}^{\mathrm{a}}$ & $-1.2 \delta^{13} \mathrm{C}^{\mathrm{a}}$ \\
\hline Pigeon & $3 / 15 / 2012$ & 16,496 & 1,914 & -790 & 1,351 & $-1,449$ \\
\hline Pigeon & $11 / 7 / 2012$ & 18,095 & 3,336 & 548 & 2,419 & -710 \\
\hline Pigeon & $9 / 10 / 2014$ & 16,586 & 2,798 & 440 & 1,069 & $-2,143$ \\
\hline Slide & $8 / 27 / 2009$ & 20,031 & 9,304 & 7,927 & 8,491 & 6,925 \\
\hline Slide & $8 / 25 / 2015$ & 19,565 & 9,174 & 7,879 & 8,440 & 7,001 \\
\hline Horse & $8 / 25 / 2015$ & 15,422 & 4,126 & 2,600 & 3,159 & 1,360 \\
\hline Upper Jumpup & $8 / 27 / 2009$ & 12,474 & 2,057 & 755 & 1,372 & -57 \\
\hline Upper Jumpup & $7 / 7 / 2015$ & 12,783 & 2,459 & 1,179 & 1,646 & 203 \\
\hline
\end{tabular}

Data values in italic show the best approximation of groundwater age. ${ }^{a} \delta^{13} C$ values represent solid carbonate 
then decreased further to $7 \mathrm{~L} / \mathrm{min}$ in 1986 and to $0 \mathrm{~L} / \mathrm{min}$ in May 1987 (Arizona Department of Environmental Quality 2010). Before June 1986, perched water encountered in the mining operations was directed to a wastewater evaporation pond (Arizona Department of Environmental Quality 2010). After June 1986, perched water was used for mining operations (Arizona Department of Environmental Quality 2010).

The tritium measured at Pigeon Spring ranges from 0.25 to $0.40 \mathrm{TU}$, which indicates that the water was recharged prior to 1952 (Eastoe et al. 2012) or that the water is a mixture of modern and old water. The tritium data do not preclude the possibility of older groundwater present in the mineshaft from contributing to Pigeon Spring; however, the regional groundwater system indicates that groundwater from the mining area would not move toward Pigeon Spring unless there is an unknown fracture connecting the mine and spring.

Geochemical and isotopic data indicate that the elevated uranium concentration at Pigeon Spring is likely related to groundwater interaction with a mineralized breccia pipe hydrologically upgradient from the spring and not related to Pigeon Mine. Before mine development at Pigeon Mine the Pigeon Spring had strongly anomalous uranium concentration of $44 \mu \mathrm{g} / \mathrm{L}$ in Billingsley et al. 1983 and they state that a possibility exists that the water which emerges in Pigeon Spring has dissolved uranium from another mineralized collapse structure similar to the one at Pigeon Pipe. Wenrich et al. 1994 noted that Pigeon Spring is topographically higher than the ore body at Pigeon Mine and that mineralized pipes tend to occur in clusters, so there is a good possibility that Pigeon Spring contains water that has flowed through one or more mineralized pipes. In addition to Pigeon Spring (elevation $1,512 \mathrm{~m}$ ) discharging groundwater above the ore body at Pigeon Mine (1,169-1,329 m), the elevation of the contacts between rock layers exposed in Snake Gulch decrease in elevation to the west between Pigeon Spring and Pigeon Mine (Billingsley et al. 2008). Two implied bedding measurements in the Kaibab Formation between Pigeon Spring and Pigeon Mine also indicate beds dipping to the northwest (Billingsley et al. 2008).

The wastewater pond site at Pigeon Mine was located northwest side of the surface expression of the breccia pipe collapse structure (Otton et al. 2010). Given the ground surface and rock unit contacts dip towards the northwest and the pond is on the edge of an inward dipping collapse feature of the Pigeon Pipe (Fig. 9), it seems likely that mine wastewater would flow towards the northwest along the regional perched groundwater gradient (Figs. 7 and 9) or down into the Pigeon Pipe and mine structures in the absence of evidence of a preferential fracture pathway between Pigeon Mine and Pigeon Spring (Gettings and Bultman 2005). The stable isotopic data for Pigeon Spring do not indicate that greater evaporation such as from water in a wastewater evaporation pond, occurred in contributing water compared to other springs in the area (Fig. 5).
Geochemical anomalies and iron mineralization are commonly found in the breccia pipes in stratigraphic units above the uranium ore in breccia pipes (Kaibab and Toroweap formations and Coconino Sandstone; Wenrich et al. 1988, 1997; Wenrich 1985; Van Gosen and Wenrich 1989). At the Hermit Mine an ore zone was found in the Toroweap Formation (Energy Fuels Nuclear Inc. 1990). Otton et al. (2010) noted elevated uranium, iron and limonite on the surface of the Kaibab Formation to the east and south of the Pigeon Mine. They suggest these zones may have formed by fluids circulating near the Pigeon Pipe during ore formation. Water discharging at Pigeon Spring most likely moved through the Kaibab and Toroweap formations, according to the strontium isotopes and potentiometric surface contours, so contact with geochemically anomalous deposits in those formations above the main uranium ore bodies are possible.

Otton et al. 2010 collected solid samples from several breccia pipe uranium mines on the north side of the Grand Canyon, including Pigeon Mine and near Jumpup Spring. Samples were collected from mining related material as well as samples around the mine site that presumably represent background concentrations from the Kaibab Formation. Otton et al. (2010) leached four of the solid samples and a sample of uranium ore from Pigeon Mine by a series of leaching experiments: a 1-h rainwater simulated deionized water (DI) leach, a 24-h rainwater simulated DI leach, and a 24-h river water simulated $300 \mathrm{mg} / \mathrm{L}$ hydrogen carbonate water leach. The leachate data indicate the greatest concentration of uranium for all samples came from the 24-h river water leach. The uranium concentration from the 24-h river water leachate from the Pigeon Mine waste rock sample PW-03 $(18,800 \mu \mathrm{g} / \mathrm{L})$ was the greater than leachate for the Pigeon Ore $(10,500 \mu \mathrm{g} / \mathrm{L})$, and were both an order of magnitude greater than the two other leachates of Pigeon Mine waste rock samples (1,290-5,480 $\mu \mathrm{g} / \mathrm{L}$; Fig. 10). One other solid sample from the Pigeon Mine area (PS-08) was leached and analyzed, and it represents a soil sample just outside the Pigeon Mine area that had elevated uranium compared with the other soil samples outside of the mining area. The sample was noted to be located just down slope of a limonite outcrop, which Otton et al. 2010 noted may be related to the elevated uranium concentration of the soil sample or could also be due to wind transport from the mining activities. The limonite deposits may represent mineralization above the breccia pipe ore body at the Pigeon Mine that is found at a number of other pipes. The uranium concentration from the PS- 08 sample 24-h river water leachate was $60.4 \mathrm{ug} / \mathrm{L}$, which is similar to the magnitude of uranium concentrations at Pigeon Spring (Fig. 10).

A multivariate principal component analysis (PCA) was conducted on the solid samples from Otton et al. 2010 to understand if there is a signature of elements associated with the Pigeon Mine material that may be distinct from soil surrounding the mine derived from the Kaibab Formation 


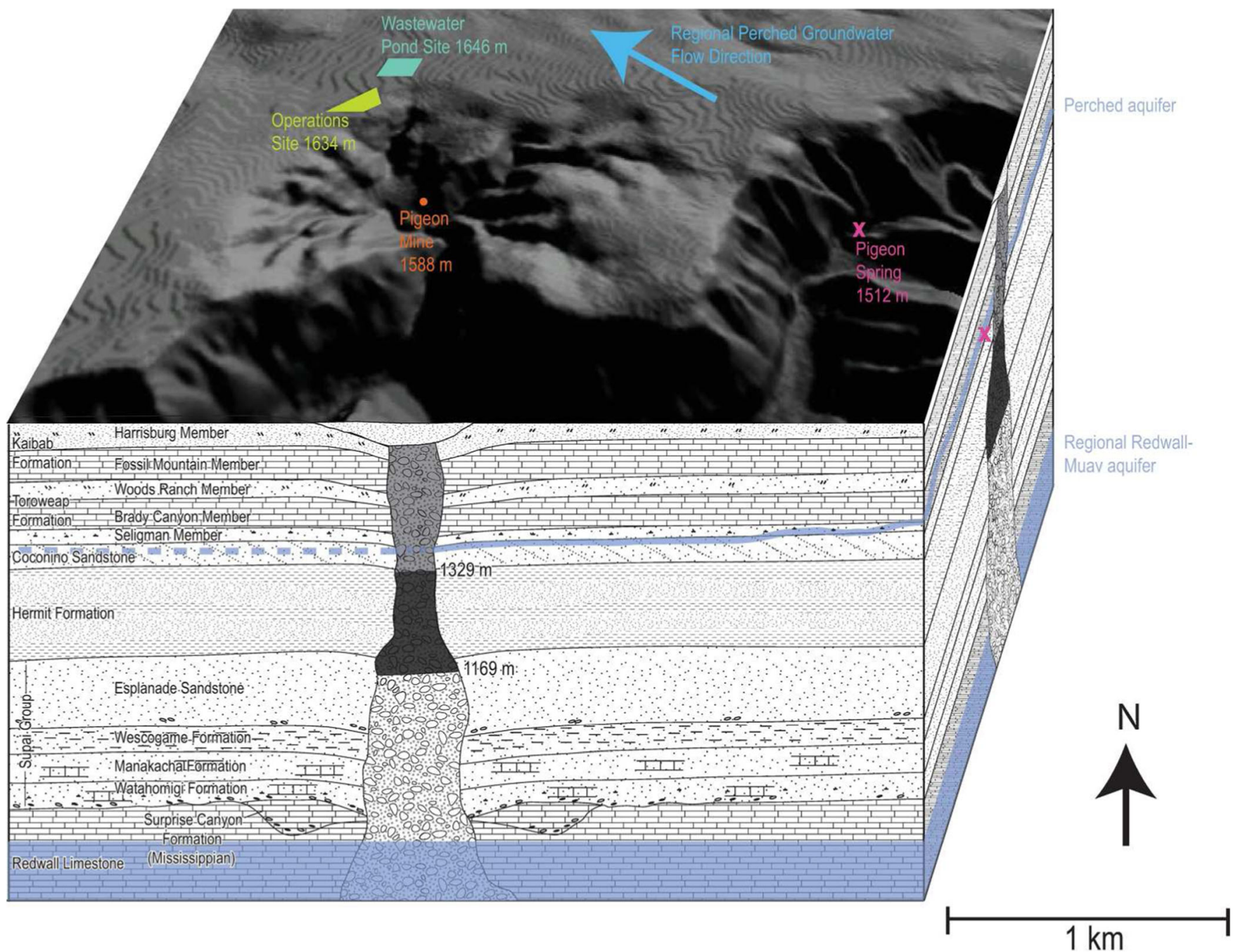

Fig. 9 Conceptual model of the area around Pigeon Mine including a digital elevation surface topography layer. The geologic cross section and depiction of the breccia pipe at Pigeon Mine and one upgradient from Pigeon Spring have been modified from Van Gosen and Wenrich 1989

(Fig. S2 of the ESM). The first principal component (PC1) and second principal component (PC2) of the PCA of the sediment, soil, rock, and ore samples explained $75.9 \%$ of the variation in the data (Fig. S2 of the ESM). Soil, ore, mud, and waste rock samples associated with mining activities have a positive association with $\mathrm{PC} 1$ which has positive loadings of the elements $\mathrm{U}, \mathrm{Cd}, \mathrm{Pb}, \mathrm{Sb}, \mathrm{As}, \mathrm{Cu}, \mathrm{Mo}$, and $\mathrm{Zn}$. The waste rock followed by ore samples are most correlated with the PC1 axis, but separate along the PC2 axis because of greater correlation of ore samples to the negative loading elements V, $\mathrm{Ce}, \mathrm{La}, \mathrm{Rb}, \mathrm{Sr}, \mathrm{Y}, \mathrm{Li}$, and Ba. Kaibab rock is most influential in defining the positive extent of PC2, which is also more associated with soils and stream sediments in areas not or less affected by mining activities. The samples related to reclaimed and mining surface soils, and mine-affected stream sediments are more correlated with the negative axis of $\mathrm{PC} 2$, but less than the ore samples. PC2 appears to explain some of the material form and the ways in which it was processed-for example, the Kaibab Formation sample material outside the mine and stream sediment upgradient of the mine are more highly correlated to the positive axis of $\mathrm{PC} 2$, while the processed and disturbed materials in and around the mine are more correlated with elements such as $\mathrm{V}, \mathrm{Ce}, \mathrm{La}, \mathrm{Rb}, \mathrm{Sr}, \mathrm{Y}, \mathrm{Li}$, and $\mathrm{Ba}$. The soil near the limonite outcrop PS-08 is more similar to the reclaimed mining sediments and stream sediment downstream of the mining activities, rather than sediments derived from the Kaibab Formation or the ore and waste rock (Fig. S2 of the ESM).

The leachate samples from Otton et al. 2010 were compared with the spring samples collected between 2009 and 2015 during this study to determine the similarity between water derived from leaching through mining materials and the springs of the study. The spring samples were more similar to each other than to the leachate samples, of which the leachate of soil near the limonite PS- 08 was most similar to the spring samples. The first two PCs explained $68.6 \%$ of the variation in the PCA of the springs and leachate data, but the water showed a similar pattern as the solid materials in that 
Fig. 10 Uranium concentrations from Pigeon Mine leachate samples (Otton et al. 2010) and recent spring samples

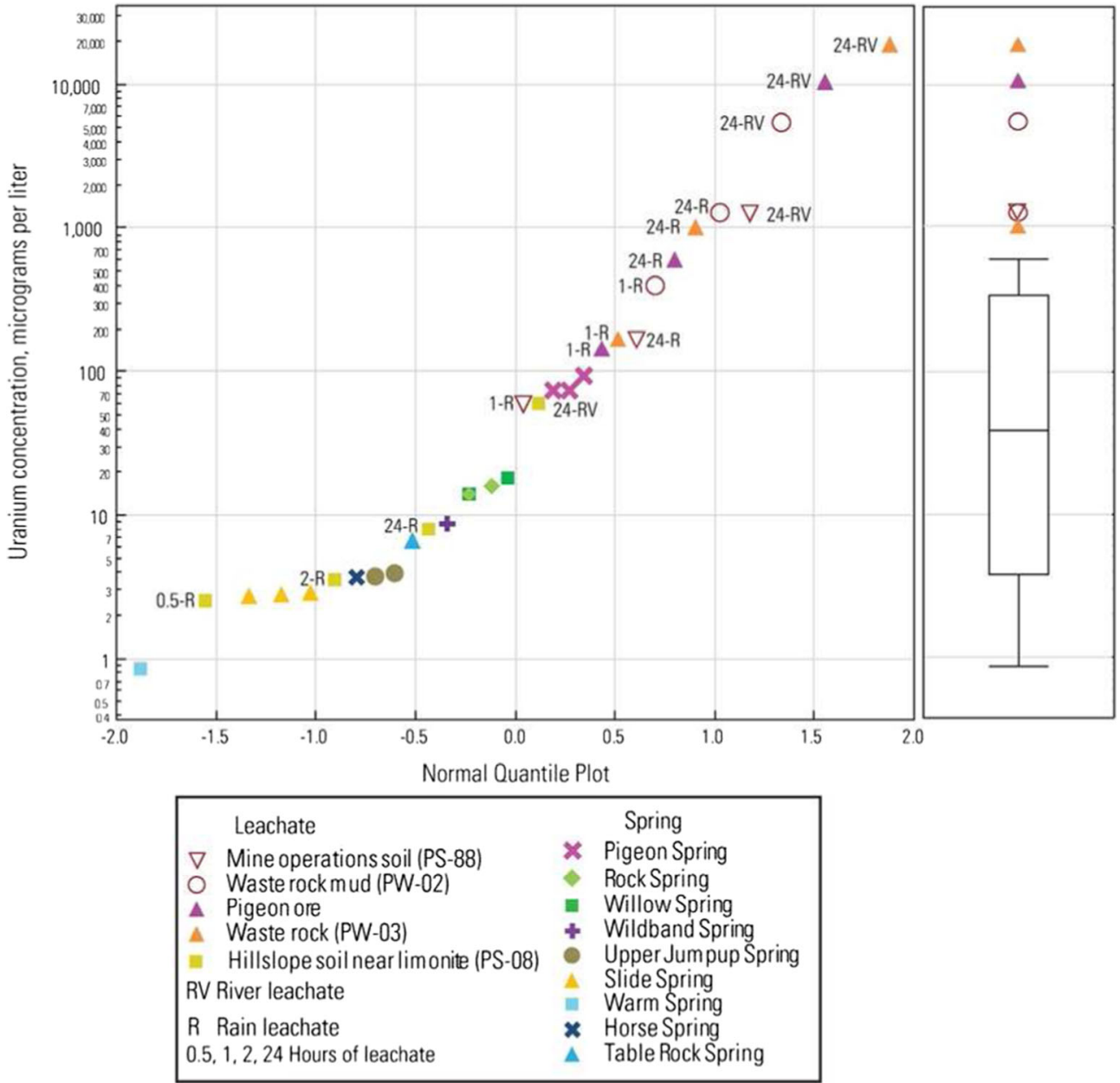

mining-activity related leachate samples separated from the spring samples along PC1 (Fig. S3a of the ESM). Leachates from mining related soils, ore, mud, and waste rock are more correlated to the elements $\mathrm{Cu}, \mathrm{Pb}, \mathrm{As}, \mathrm{Mn}$, and $\mathrm{Cd}$. Waste rock samples are most highly correlated with the positive axis of PC1 and PC2 (high loadings for Y, Ce, and La), resulting in greater separation from other samples in the PCA plot. Leaching processes also show a potential pattern with multivariate dispersion (spread of samples) being less for waste mud and mine operations soil samples as compared to waste rock, ore, and limonite, which appear to more reactive to rainwater leaching. The short-term $(1 \mathrm{~h})$ rain leachate of the waste rock defined the most positive coordinate along PC1 and PC2, whereas the $24 \mathrm{~h}$ river water ore leachate sample defined the most negative value along PC2. The negative axis of PC2 had higher loadings of the elements Mo, Sb, and V. The soil near the limonite PS-08 was most similar to the spring samples and the short-term rain leachate plotted closest to the springs.

A PCA on only the spring samples resulted in PC1 and PC2 explaining 54.2\% of the variation in the spring sample data set. PC1 is the primary gradient for which samples are separating in the PCA plot. The elements $\mathrm{U}, \mathrm{Sr}, \mathrm{Li}$, and $\mathrm{Mo}$ have high negative loadings on PC1 and Pigeon, Willow, Rock, and Wildband Spring samples are correlated with the negative axis of PC1 (Fig. S3b of the ESM). Zinc is the primary element positively loading on PC1 that distinguishes Upper Jumpup, Slide, Warm, Horse, and Table Rock springs from the other springs. The elements $\mathrm{Rb}, \mathrm{Se}$, and As have greater positive loadings on $\mathrm{PC} 2$, whereas $\mathrm{Ba}, \mathrm{Cu}, \mathrm{Pb}$, and $\mathrm{Y}$ have greater negative loadings. The sample from Wildband Spring has the greatest correlation with the negative axis of PC2, while samples from Willow, Horse, Table Rock, and Warm springs are less correlated. The subset and reanalysis of PCA for the springs indicated that Pigeon Spring was significantly similar (cluster analysis grouping) to Rock and Willow springs and that $\mathrm{U}, \mathrm{Sr}, \mathrm{Li}$, and Mo were loading highly along this axis (Fig. S3b of the ESM). These spring samples were separated from Upper Jumpup and Slide springs, which are significantly similar and can be explained by the high loading of $\mathrm{Zn}$ on this axis along with Horse, Table Rock and Warm springs (Fig. S3b of the ESM).

While U concentrations are highest at Pigeon Spring, the PCA suggests that composition of the other elements makes Pigeon Spring more similar to Rock, and Willow springs 
compared with mining material leachate. Mining leachates separated from the spring samples primarily due to differences in $\mathrm{Cu}, \mathrm{Pb}, \mathrm{As}, \mathrm{Mn}$, and $\mathrm{Cd}$ concentrations and these concentrations are not anomalously elevated at Pigeon Spring compared to the other samples in the study area (Fig. S3a of the ESM).

\section{Conclusions}

Two general groups of perched groundwater springs from Snake Gulch and Jumpup Canyon were identified from this study. The first is characterized by calcium-sulfate-type water, low UAR values, and low tritium values indicating some component of modern recharge (Pigeon, Rock, Willow, Wildband and Table Rock springs). The second is characterized by calcium-magnesium sulfate type water, higher UAR values, radiocarbon ages indicating recharge on the order of thousands of years ago and very low tritium (Slide, Upper Jumpup and Horse springs). Warm Spring represents a calcium-magnesium hydrogen carbonate-sulfate type water, with the greatest UAR, low tritium and represents modern water which likely recharged at a higher elevation compared with the Snake Gulch Springs and Upper Jumpup Spring.

Sediments derived from mining related material are distinct from sediments derived from the Kaibab Formation primarily related to $\mathrm{U}, \mathrm{Cd}, \mathrm{Pb}, \mathrm{Sb}, \mathrm{As}, \mathrm{Cu}, \mathrm{Mo}$, and $\mathrm{Zn}$. Water leached from the mining sediments at Pigeon Mine are distinct compared with the perched groundwater springs from this study for $\mathrm{Cu}$, $\mathrm{Pb}, \mathrm{As}, \mathrm{Mn}$, and $\mathrm{Cd}$, and these elements may provide a good indication of connection of waters with mining related materials.

Pigeon Spring has elevated uranium compared to the other springs in the area, but the concentration is more similar to leachate from soil derived from an iron-enriched outcrop located stratigraphically above the main uranium ore body of a mineralized breccia pipe than it is to the ore or processed mining material. Iron mineralization and an enriched trace element suite similar to the uranium ore is known to occur in the Kaibab and Toroweap formations and Coconino Sandstones above the uranium ore in some mineralized breccia pipes. Pigeon Spring discharges from the Toroweap Formation near the Coconino Sandstone contact and strontium isotopes indicate the water at Pigeon Spring may have moved through the Kaibab and Toroweap formations. The perched groundwater flow in the area is moving towards the northwest and does not support groundwater movement from the Pigeon Mine towards Pigeon Spring. Further investigation into the groundwater elevation between Pigeon Mine and Pigeon Spring and upgradient of Pigeon Spring is needed to constrain the source of elevated uranium at Pigeon Spring. Wastewater from Pigeon Mine may be also be moving through the subsurface and further investigation downgradient of the mine is also important.
Acknowledgements The geochemical and hydrologic investigation presented in this paper was supported by the USGS Toxic Substances Hydrology Program and the Bureau of Land Management. USGS employees Jessica Anderson, Jamie Macy, Kurt Schonauer, Joel Unema, Corey Sannes, and Geoff Debenedetto from the Arizona Water Science Center were critical in helping collect the spring samples from often remote locations. David Parkhurst (USGS) provided technical direction and support. We also thank two anonymous reviewers for their contribution.

Open Access This article is distributed under the terms of the Creative Commons Attribution 4.0 International License (http:// creativecommons.org/licenses/by/4.0/), which permits unrestricted use, distribution, and reproduction in any medium, provided you give appropriate credit to the original author(s) and the source, provide a link to the Creative Commons license, and indicate if changes were made.

\section{References}

Alpine AE, Brown KM (2010) Introduction. In: Alpine A (ed) Hydrological, geological, and biological sites characterization of breccia pipe uranium deposits in northern Arizona. US Geol Surv Sci Invest Rep 2010-5025

Anderson RS, Betancourt JL, Mead JI, Hevly RH, Adam DP (2000) Middle- and late-Wisconsin paleobotanic and paleoclimatic records from the southern Colorado Plateau, USA. Palaeogeogr Palaeoclimatol Palaeoecol 155:31-57

Antweiler RC, Taylor HE (2008) Evaluation of statistical treatments of left-censored environmental data using coincident uncensored data sets: I. summary statistics. Environ Sci Technol 42:3732-3738

Appelo CAJ, Postma D (2005) Geochemistry, groundwater and pollution, 2nd edn. Balkema, London

Arizona Department of Environmental Quality (2010) Pigeon Mine water discharge graph. ADEQ, Phoenix, AZ

Arizona Game and Fish (2015) Arizona's ecoregions and vegetative communities. Arizona Game and Fish Department, Phoenix, AZ

Billingsley GH, Antweiler JC, Ellis CE (1983) Mineral resource potential of the Kanab Creek roadless area, Coconino and Mohave counties, Arizona. US Geol Surv Misc Field Study MF-1627-A

Billingsley GH, Priest SS, Felger TJ (2008) Geologic map of the Fredonia $30^{\prime} \times 60^{\prime}$ quadrangle, Mohave and Coconino counties, Northern Arizona. US Geol Surv Sci Invest Map 3035

Bills DJ, Flynn ME, Monroe SA (2007) Hydrogeology of the Coconino Plateau and adjacent areas, Coconino and Yavapai counties, Arizona. US Geol Surv Sci Invest Rep 2005-5222

Bills DJ, Tillman FD, Anning DW, Antweiler RC, Kraemer TF (2010) Historical and 2009 water chemistry of wells, perennial and intermittent streams, and springs in northern Arizona. In: Alpine A (ed) Hydrological, geological, and biological sites characterization of breccia pipe uranium deposits in northern Arizona. US Geol Surv Sci Invest Rep 2010-5025

Bullen TD, Krabbenhoft D, Kendall C (1996) Kinetic and mineralogic controls on the evolution of groundwater chemistry and $87 \mathrm{Sr} / 86 \mathrm{Sr}$ in a sandy silicate aquifer, northern Wisconsin. Geochim Cosmochim Acta 60(10):1807-1821

Charlton SR, Parkhurst DL (2002) PHREEQCI-A graphical user interface to the geochemical model. US Geol Surv Fact Sheet PHREEQC FS-031-02

Clarke KR, Warwick RM (2001) Change in marine communities: an approach to statistical analysis and interpretation, chap 4. In: 
Clarke KR, Gorley RN (eds) PRIMER-E, 2nd edn. PRIMER-E, Plymouth, UK, 8 pp

Cowart JB, Osmond JK (1977) Uranium isotopes in groundwater: their use for prospecting for sandstone-type uranium deposits. Geochem Explor 8:365-379

Craig H (1961) Isotopic variations in meteoric waters. Science 133:17021703

Eastoe CJ, Watts CJ, Ploughe M, Wright WE (2012) Future use of tritium in mapping pre-bomb groundwater volumes. Ground Water 50(1): 87-93

Energy Fuels Nuclear (1990) Review of shaft and raise closure plan at the Hermit Mine of Energy Fuels Nuclear, Inc. Behre Dolbear, Greenwood Village, CO

Farnsworth RK, Thompson ES, Peck EL (1982) Evaporation atlas for the contiguous 48 United States. Nat Ocean Atmos Admin Tech Rep NWS33, NOAA, Silver Spring, MD

Farquhar GD, Ehleringer JR, Hubick KT (1989) Carbon isotope discrimination and photosynthesis. Ann Rev Plant Physiol Plant Mol Biol 40:503-537

Finch WI, Pierson CT, Sutphin HB (1992) Grade and tonnage model of solution collapse breccia pipe uranium deposits: In: Bliss JD (ed) Developments in mineral deposit modeling. US Geol Surv Bull 2004, pp 36-38

Flint LE, Flint AL (2007) Regional analysis of ground-water recharge: In: Stonestrom DA, Constantz J, Ferre TPA, Leake SA (eds) Groundwater recharge in the arid and semi-arid southwestern United States. US Geol Surv Prof Pap 1703

Garbarino JR, Taylor HE (1979) An inductively-coupled plasma atomicemission spectrometric method for routine water quality testing. Appl Spectrosc 33:220-226

Garbarino JR, Taylor HE (1996) Inductively-coupled plasma-mass spectrometric method for the determination of dissolved trace elements in natural water. US Geol Surv Open-File Rep 94-358, 49 pp

Gettings ME, Bultman MW (2005) Candidate-penetrative-fracture mapping of the Grand Canyon Area, Arizona, from spatial correlation of deep geophysical features and surficial lineaments. US Geol Surv Digital Ser 121

Hageman PL, Briggs PH (2000) A simple field leach for rapid screening and qualitative characterization of mine waste material on abandoned mine lands, in ICARD 2000. Proceedings from the 5th International Conference on Acid Rock Drainage, Denver, CO, May 21-24, 2000, Society for Mining, Metallurgy, and Exploration, Englewood, CO, pp 1463-1475

Han L-F, Plummer LN (2013) Revision of Fontes \& Garnier's model for the initial $14 \mathrm{C}$ content of dissolved inorganic carbon used in groundwater dating. Chem Geol 351:105-114

Han LF, Plummer LN (2016) A review of single-sample-based models and other approaches for radiocarbon dating of dissolved inorganic carbon in groundwater. Earth-Sci Rev 152:119-142

Han L-F, Plummer LN, Aggarwal P (2012) A graphical method to evaluate predominant geochemical processes occurring in groundwater systems for radiocarbon dating. Chem Geol 318-319:88-112

Hart R, Nelson ST, Eggett D (2010) Uncertainty in 14C model ages of saturated zone waters: the influence of soil gas in terranes dominated by C3 plants. J Hydrol 392:83-95. doi:10.1016/j.jhydrol.2010.08.001

Hopkins RT, Fox JP, Campbell WL, Antweiler JC (1984) Analytical results and sample locality map of stream-sediment, panned-concentrate, soil, and rock samples from the Kanab Creek (B3060) Roadless Area, Coconino Mohave counties, Arizona. US Geol Surv Open-File Rep 84-291

Huntoon PW (1996) Large-basin ground water circulation and paleoreconstruction of circulation leading to uranium mineralization in Grand Canyon Breccia Pipes, Arizona. Mt Geol 33(3):71-84

Ingerson E, Pearson FJ Jr (1964) Estimation of age and rate of motion of ground water by the $14 \mathrm{C}$ method. In: Recent researches in the fields of hydrosphere, atmosphere and nuclear geochemistry. Editorial Committee for Sugawara Volume, Maruzen, Tokyo, pp 263-283

Kraemer TF, Doughten MW, Bullen TD (2002) Use of ICP/MS with ultrasonic nebulizer for routine determination of uranium activity ratios in natural water. Environ Sci Technol 36:4899-4904

Kronfeld J (1974) Uranium deposition and Th-234 alpha recoil; an explanation for extreme U-234/U-238 fractionation within the Trinity aquifer. Earth Planet Sci Lett 21:327-330

Lamothe PJ, Meier AL, Wilson SA (2002) The determination of forty-four elements in aqueous samples by inductively coupled plasma-mass spectrometry, chap H. In: Taggart JE (ed) Analytical methods for chemical analysis of geologic and other materials. US Geol Surv Open-File Rep 2002-223-H, 11 pp. http://pubs.usgs.gov/of/2002/ofr02-0223/. Accessed 18 Nov 2009

Monroe SA, Antweiler RC, Hart RJ, Taylor HE, Truini Margot Rihs JR, Felger TJ (2005) Chemical characteristics of ground-water discharge along the south rim of Grand Canyon in Grand Canyon National Park, Arizona, 2000-2001. US Geol Surv Sci Invest Rep 2004-5146, $59 \mathrm{pp}$

Osmond JK, Cowart JB (1976) The theory and uses of natural uranium isotopic variations in hydrology. Atomic Energy Rev 14:620-679

Otton JK, Van Gosen BS (2010) Uranium resource availability in breccia pipes in northern Arizona: In: Alpine A (ed) Hydrological, geological, and biological sites characterization of breccia pipe uranium deposits in northern Arizona. US Geol Surv Sci Invest Rep 2010-5025

Otton JK, Gallegos TJ, Van Gosen BS, Zielinski RA, Johnson RH, Hall SM, Arnold LR, Yager DB (2010) Effects of 1980s uranium mining in the Kanab Creek area of northern Arizona. In: Alpine A (ed) Hydrological, geological, and biological sites characterization of breccia pipe uranium deposits in northern Arizona. US Geol Surv Sci Invest Rep 2010-5025

Parkhurst DL, Appelo CAJ (2013) Description of input and examples for PHREEQC version 3: a computer program for speciation, batchreaction, one-dimensional transport, and inverse geochemical calculations. US Geol Surv Tech and Methods, book 6, chap A43, USGS, Reston, VA, $497 \mathrm{pp}$

Parkhurst DL, Charlton SR (2008) NetpathXL: an Excel® interface to the program. NETPATH: US Geol Surv Tech and Methods 6-A26, USGS, Reston, VA, 11 pp

Pendall EG (1997) Precipitation seasonality recorded in D/H ratios of Pinyon Pine cellulose in the Southwestern United States. PhD Thesis, Univ of Arizona, Tuscon, AZ, USA

Plummer LN, Bexfield LM, Anderholm SK, Sanford WE, Busenberg E (2012) Geochemical characterization of ground-water flow in the Santa Fe Group aquifer system, Middle Rio Grande Basin, New Mexico (ver. 1.2, November 20, 2012). US Geol Surv Water Resour Invest Rep 03-04131, 395 pp

PRISM Climate Group (2015) United States average annual precipitation, 1931-2010. Oregon State University, PRISM Climate Group, Corvallis, OR. http://www.prism.oregonstate.edu/normals/. Accessed 22 Dec 2015

Révész K, Coplen TB (2008a) Determination of the $\delta\left({ }^{2} \mathrm{H} /{ }^{1} \mathrm{H}\right)$ of water: RSIL lab code 1574 , chap C1. In: Révész K, Coplen TB (eds) Methods of the Reston stable isotope laboratory. US Geol Surv Tech and Methods, book 10, chap C1, USGS, Reston, VA, 27 pp

Révész K, Coplen TB (2008b) Determination of the $\delta\left({ }^{18} \mathrm{O} /{ }^{16} \mathrm{O}\right)$ of water: RSIL lab code 489, chap C2. In: Révész K, Coplen TB (eds) Methods of the Reston stable isotope laboratory. US Geol Surv Tech and Methods, book 10, chap C2, USGS, Reston, VA, 28 pp

Szabo BJ (1982) Extreme fractionation of ${ }^{234} U /{ }^{238} U$ and ${ }^{230} \mathrm{Th} /{ }^{234} \mathrm{U}$ in spring waters, sediments, and fossils at the Pomme de Terre valley, southwestern Missouri. Geochim Cosmochim Acta 46:1675-1679

Tamers MA (1967) Radiocarbon ages of groundwater in an arid zone unconfined aquifer. In: Isotope techniques in the hydrological cycle, AGU Monograph 11, AGU, Washington, DC, pp 143-152, doi:10.1029/GM011p0143 
Tamers MA (1975) Validity of radiocarbon dates on groundwater. Geophys Surv 2:217-239

Tamers MA, Scharpenseel HW (1970) Sequential sampling of radiocarbon in groundwater. In: Isotope Hydrology 1970. International Atomic Energy Agency, Vienna, pp 241-256

Taylor HE (2001) Inductively coupled plasma-mass spectrometry: practices and techniques. Academic, New York, 294 pp

US Department of the Interior (2012) Record of Decision: Northern Arizona withdrawal: Mohave and Coconino counties, Arizona.http://www.blm. gov/pgdata/etc./medialib/blm/az/pdfs/withdraw/feis.Par.88586.File. dat/NorthernArizona-ROD- v20-1\%2011\%202012_wsignederrata. pdf. Accessed 26 May 2016

US Geological Survey (2015) National Water Information System: US Geological Survey database. http://waterdata.usgs.gov/nwis. Accessed 18 Nov 2015

US Geological Survey (variously dated) National field manual for the collection of water-quality data: US Geol Surv Tech of WaterResour Invest, book 9, chaps A1-A10. http://pubs.water.usgs. gov/twri9A. Accessed November 2016

UNESCO (2016) World Heritage List: Grand Canyon. http://whc.unesco. org/en/list/75. Accessed 26 May 2016

Van Gosen BS, Wenrich KJ (1989) Ground magnetometer surveys over known and suspected breccia pipes on the Coconino Plateau, northwestern Arizona. US Geol Surv Bull 1683-C, 31 pp
Vogel JC (1993) Variability of carbon isotope fractionation during photosynthesis. In: Ehleringer JR et al (eds) Stable isotopes and plant carbon-water relations. Academic, London, pp 29-46

Wenrich KJ (1985) Mineralization of breccia pipes in Northern Arizona. Econ Geol 80:1722-1735

Wenrich KJ, Van Gosen BS, Balcer RA, Scott JH, Mascarenas JF, Bedinger GM, Burmaster Betsi (1988) A mineralized breccia pipe in Mohawk Canyon: lithologic and geophysical logs. US Geol Surv Bull 1683-A, 66 pp

Wenrich KJ, Chenoweth WL, Finch WI, Scarborough RB (1989) Uranium in Arizona: In: Jenney JP, Reynolds SJ (eds) Geologic evolution of Arizona. Arizona Geol Soc Dig 17:759-794

Wenrich KJ, Boundy SQ, Aumente-Modreski R, Schwarz SP, Sutphin HB, Been JM (1994) A hydrogeochemical survey for mineralized breccia pipes: data from springs, wells, and streams on the Hualapai Indian Reservation, northwestern Arizona. US Geol Surv Open-File Rep 93-619

Wenrich KJ, Billingsley GH, Huntoon PW (1997) Breccia-pipe and geologic map of the northeastern part of the Hualapai Indian Reservation and Vicinity, Arizona. US Geol Surv Misc Invest Series Map I-2440

Western Regional Climate Center (2016) Western Regional Climate Center, Page Arizona station KPGA January 1997-December 2008. http://www.wrcc.dri.edu/. Accessed 8 June 2016 